
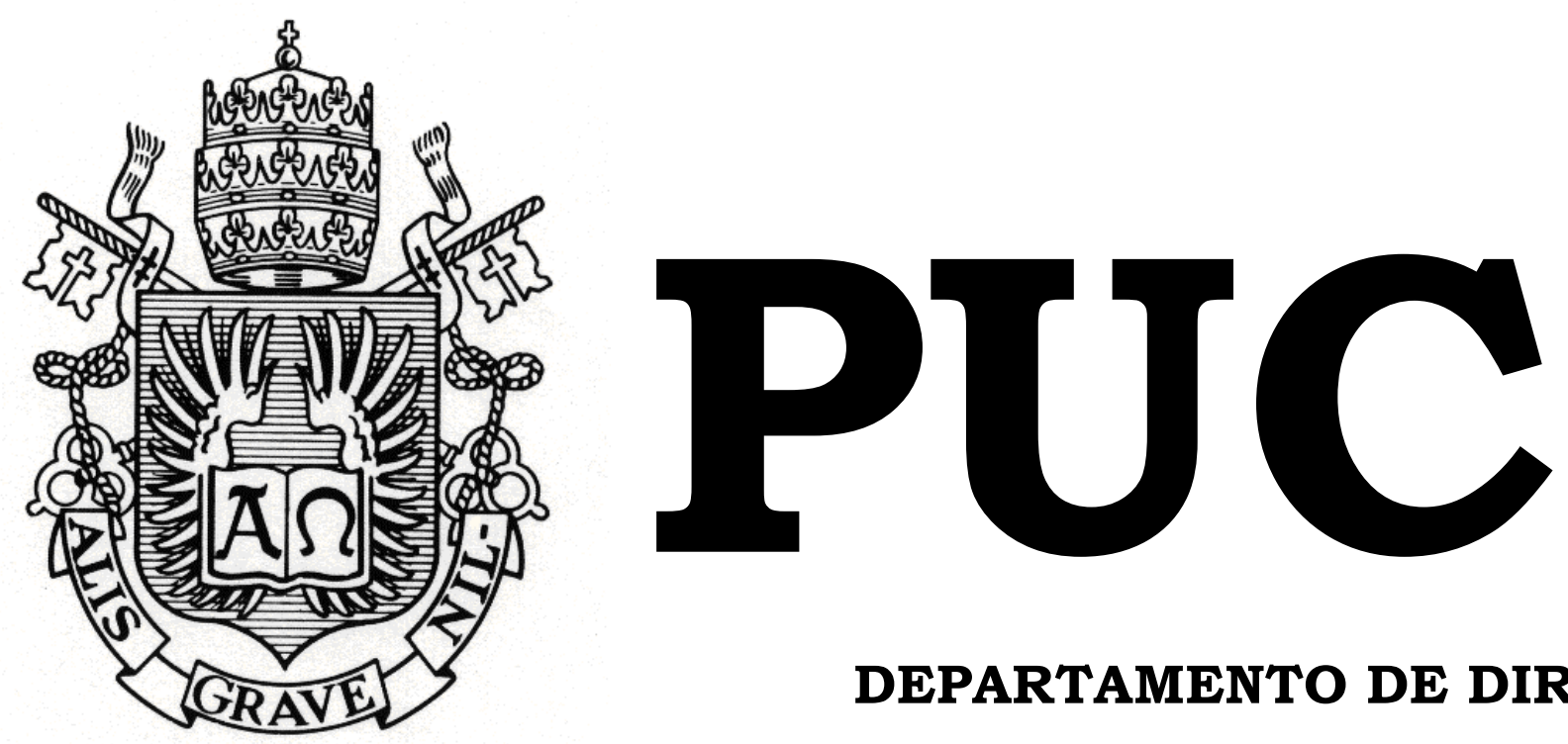

DEPARTAMENTO DE DIREITO

\title{
ATOS DE DISPOSIÇÃO SOBRE O PRÓPRIO CORPO: O CASO DA BODYMODIFICATION
}

\author{
por \\ LUÍSA BARAN DE MELLO ALVARENGA \\ ORIENTADOR: CARLOS NELSON KONDER \\ 2010.2
}

PONTIFÍCIA UNIVERSIDADE CATÓLICA DO RIO DE JANEIRO RUA MARQUÊS DE SÃO VICENTE, 225 - CEP 22453-900 RIO DE JANEIRO - BRASIL 


\title{
ATOS DE DISPOSIÇÃO SOBRE O PRÓPRIO CORPO: O CASO DA BODYMODIFICATION
}

\author{
por \\ LUÍSA BARAN DE MELLO ALVARENGA
}

Monografia apresentada ao

Departamento de Direito da

Pontifícia Universidade Católica do

Rio de Janeiro (PUC-Rio) para a obtenção do Título de Bacharel em Direito.

Orientador: Carlos Nelson Konder 


\section{Resumo}

O Código Civil de 2002, ao tratar dos direitos da personalidade, restringiu a prática de atos de disposição sobre o próprio corpo que causem diminuição permanente da integridade física e violem os bons costumes, ressalvando apenas os casos autorizados pela exigência médica. Porém, em decorrência do processo de constitucionalização do direito civil, a tutela da personalidade passou a ser delineada a partir da dignidade da pessoa humana, valor central do ordenamento jurídico brasileiro, tornando-se necessária a relativização dessa rígida indisponibilidade do corpo humano. A autonomia privada existencial, categoria na qual se insere a autonomia corporal, é um poderoso instrumento de manifestação e desenvolvimento da personalidade, razão pela qual se deve assegurar aos indivíduos ampla liberdade de escolha no que tange aos seus interesses existenciais. No entanto, a respeito do consentimento nos atos de disposição sobre o próprio corpo, é preciso analisar a sua legitimidade sob a ótica da dignidade da pessoa humana, de modo que eles somente serão dignos de tutela quando importarem na promoção da personalidade. Então, sendo a prática da bodymodification uma expressão da identidade pessoal dos seus adeptos e, portanto, uma forma de exaltação da personalidade, deve ser garantida aos indivíduos plena liberdade para a realização das alterações corporais.

\section{Palavras-Chave}

Dignidade da pessoa humana; personalidade; autonomia; corpo; bodymodification. 


\section{Sumário}

Introdução 5

1) A Constitucionalização do Direito Civil.......................................

1.1) A atividade hermenêutica à luz da doutrina civil-constitucional.......8

1.2) A superação da dicotomia entre direito público e direito privado .11

2) Dignidade da Pessoa Humana e a Tutela da Personalidade. 14

2.1) O princípio da dignidade da pessoa humana................................14

2.2) A dignidade da pessoa humana como cláusula geral de tutela da personalidade............................................................................... 16

2.3) Autonomia privada patrimonial e existencial...............................22

3) Atos de Disposição sobre o Próprio Corpo .27

3.1) Interpretação civil-constitucional do artigo 13 do Código Civil.....27

3.2) Autonomia corporal e a tutela da integridade psicofísica.

3.3) Os limites da autonomia corporal à luz da dignidade da pessoa humana............................................................... 34

3.3.1) O consentimento nos atos de disposição sobre o próprio corpo. .34

3.3.2) Liberdade $X$ Integridade: conflito entre aspectos da dignidade da pessoa humana. .39

4) O Caso da Bodymodification

4.1) A bodymodification como ato de disposição sobre o próprio corpo. .42

4.2) A bodymodification como forma de manifestação da personalidade.

Conclusão

Referências Bibliográficas.. .52

Anexo I 


\title{
Abreviações e símbolos
}

\author{
Art. - Artigo \\ CC - Código Civil \\ CF - Constituição Federal \\ Ex. - Exemplo \\ $\mathrm{n}^{\mathrm{o}}$ - número \\ p. - página \\ vol. - volume
}




\section{Introdução}

Com o processo de constitucionalização do direito e a consequente superação da dicotomia entre direito público e direito privado, a Constituição Federal de 1988 assumiu a função de elemento centralizador do sistema jurídico, de modo que todos os ramos do direito passaram a ser interpretados e aplicados de acordo com suas normas e princípios. Com isso, a dignidade da pessoa humana, consagrada como fundamento da República, foi alçada à categoria de valor supremo do ordenamento constitucional brasileiro, determinando a adequação de todos os institutos jurídicos à sua tutela e promoção.

$\mathrm{Na}$ esfera cível, a constitucionalização do direito incentivou a ampliação do conceito de personalidade, que passou a abranger também o seu aspecto existencial, em detrimento da antiga visão meramente patrimonial. No mesmo sentido, a dignidade da pessoa humana recebeu o título de cláusula geral de tutela da personalidade, de maneira a garantir a ampla proteção e desenvolvimento da pessoa em todas as situações subjetivas existenciais em que estiver envolvida e não apenas nos casos tipificados em lei.

Ademais, o Código Civil de 2002 consagrou os direitos da personalidade, assim entendidos como o direito à integridade física, ao nome, à imagem, à honra e à privacidade. No entanto, no que tange ao exercício desses direitos, o artigo 11 do diploma civilista impôs certas limitações, tornando-os indisponíveis, intransmissíveis e irrenunciáveis.

Em relação à integridade física, o artigo 13 do Código Civil seguiu a mesma linha de raciocínio e, igualmente, restringiu a autonomia corporal. Somente foram permitidos atos de disposição sobre o próprio corpo que não causem diminuição permanente da integridade física e não violem os bons costumes, com exceção apenas dos casos justificados pela exigência médica. 
Discordando da posição restritiva do legislador, a doutrina civilconstitucional proclamou a importância da autonomia privada nas relações extrapatrimoniais como instrumento de livre desenvolvimento da personalidade e, consequentemente, como forma de realização dos princípios constitucionais na direção da concretização da dignidade da pessoa humana. Entende-se, portanto, que tais dispositivos do Código Civil devem ser interpretados de acordo com a Constituição, sendo imprescindível assegurar total liberdade de autodeterminação aos indivíduos para regular seus interesses existenciais, de maneira a possibilitar a promoção da personalidade.

Entretanto, a respeito da autonomia corporal, tendo em vista a evolução incessante dos recursos médicos e científicos, bem como a possibilidade de conflitos entre valores constitucionalmente assegurados, faz-se necessário avaliar até que ponto os atos de disposição sobre o próprio corpo podem ser considerados legítimos e merecedores de tutela jurídica.

Então, o presente estudo busca analisar a importância da autonomia corporal para o livre desenvolvimento da personalidade, bem como verificar quais restrições devem ser impostas à autodeterminação corporal em nome da dignidade da pessoa humana.

Para tanto, terá como foco principal a bodymodification, uma prática de modificação deliberada e permanente do corpo humano por motivos de ordem estética, cultural ou espiritual. É o caso, por exemplo, do homemtigre e do homem-lagarto, pessoas que tinham o desejo de se tornar animais e, para tanto, fizeram diversas tatuagens pelo corpo, implantes subcutâneos de esferas de silicone e piercings no rosto, bifurcaram suas línguas e modelaram seus dentes.

De início, serão analisadas as premissas básicas necessárias à construção do raciocínio apresentado: a constitucionalização do direito e a consagração da dignidade da pessoa humana como cláusula geral de tutela da personalidade. 
A seguir, será destacada a necessidade de interpretação constitucional dos rígidos limites impostos pelo artigo 13 do Código Civil, em razão da importância da autonomia corporal para garantir o livre desenvolvimento da personalidade. Ademais, verificar-se-á a legitimidade do consentimento nos atos de disposição sobre o próprio corpo, mediante ponderação dos valores conflitantes, à luz da dignidade da pessoa humana.

Por fim, será exposta a prática da bodymodification através de alguns de seus exemplos e a necessidade do seu reconhecimento como forma de manifestação da personalidade e da identidade pessoal e, consequentemente, como mecanismo de realização da dignidade da pessoa humana 


\section{1) A Constitucionalização do Direito Civil}

\section{1) A atividade hermenêutica à luz da doutrina civil-constitucional}

A base do pensamento jurídico europeu do século XIX foi fortemente influenciada pelos ideais burgueses da Revolução Francesa, consagrando o liberalismo jurídico, corrente ideológica calcada no indivíduo e na propriedade. Esse movimento teve assento no Código de Napoleão, cuja principal preocupação era preservar a autonomia da vontade patrimonial, de maneira a garantir juridicamente um sistema de livre contratação e circulação de riquezas, a salvo de qualquer forma de interferência estatal.

A partir dessa base teórica, foi inaugurado o Estado Liberal, fundado na igualdade formal entre os indivíduos e na liberdade econômica. Protegiase, primordialmente, a propriedade privada e a autonomia da vontade, sendo os indivíduos livres para regular as suas relações patrimoniais.

Nesse período, fez-se presente a divisão entre o direito público e o direito privado, de modo que quase não havia diálogo entre essas duas esferas. De um lado, as Constituiçõos regulavam as relações entre o Estado e o cidadão, enquanto que ao direito civil cabia a normatização das relações jurídicas privadas, sem qualquer espaço para a aplicação das normas constitucionais.

Predominou, nessa época, a tendência à codificação, sendo o Código Civil o estatuto único de regulamentação das relações particulares, não havendo possibilidade de interferência do direito público nas questões patrimoniais. Por outro lado, o papel da Constituição era limitado, 
constituindo apenas um instrumento de convocação à atuação dos poderes públicos, cuja concretização dependia da intermediação do legislativo ${ }^{1}$.

No final do século XIX e início do século XX, porém, a intensificação das lutas sociais decorrentes do processo de industrialização e principalmente a Primeira Guerra Mundial levaram à necessidade de uma maior intervenção estatal na economia. As Constituições européias, inspiradas na Constituição Alemã de Weimar de 1919, incorporaram os direitos sociais aos seus textos, derrubando a ideia de igualdade formal antes predominante, fator determinante para a formação do Estado Social.

Diante de tais acontecimentos e em razão da crescente intervenção do poder público na economia, as bases do liberalismo jurídico entraram em crise. Como conseqüência, o direito civil oitocentista e os seus fundamentos - a propriedade privada e o contrato - tiveram que se adequar às novas diretrizes jurídicas que passaram a vigorar.

No Brasil, este movimento mundial foi traduzido, a partir dos anos 30, pelo aumento exponencial de criação de leis extravagantes, contrárias à principiologia do Código Civil de 1916, que retiraram dele o seu caráter de “Constituição do direito privado". Através de tais leis, o legislador brasileiro, sob forte influência da política do Welfare State, promoveu intensa intervenção assistencialista, limitando a autonomia da vontade individual. Assim, o principal diploma civil deixou de regular exclusivamente as relações patrimoniais, abrindo espaço para a criação de microssistemas jurídicos apartados.

Com a intensificação da intervenção estatal nas relações patrimoniais, há o surgimento da chamada "Era dos Estatutos", visto que as leis extracodificadas passaram a disciplinar setores inteiros do direito privado, preocupando-se, inclusive, com as relações existenciais. É o caso,

\footnotetext{
${ }^{1}$ BARROSO, Luis Roberto. Neoconstitucionalismo e constitucionalização do direito (o triunfo tardio do direito constitucional no Brasil). Revista Eletrônica sobre a Reforma do Estado - RERE, n. 09, 2007, p. 24.
} 
por exemplo, do Código de Defesa do Consumidor, da Lei de Locações e do Estatuto da Criança e do Adolescente.

O Código Civil de 1916 perde, então, a sua posição hegemônica e assume a condição de lei periférica e supletiva do direito privado, sendo aplicado somente aos casos não regulados pelas leis especiais e normas constitucionais.

Diante desse novo contexto e tendo em vista o surgimento do Estado Democrático de Direito, a Constituição passa a exercer o importante papel de elemento centralizador do ordenamento jurídico, harmonizando a legislação infraconstitucional através dos seus princípios e valores. Nesse sentido, de modo a se buscar a unidade do sistema, há o deslocamento para a tábua axiológica da Constituição o ponto de referência antes localizado no Código Civil ${ }^{2}$. Por conseguinte, torna-se imprescindível a redefinição do direito privado sob a ótica da Constituição Federal de 1988, concretizando a constitucionalização do direito civil.

Assim, todo o Código Civil e a legislação infraconstitucional de direito privado devem ser reinterpretados conforme a principiologia consagrada na nova Carta Política. Ao intérprete cabe redesenhar o conteúdo dos institutos de direito privado de forma a compatibilizá-los com os novos fundamentos do ordenamento constitucional brasileiro, principalmente com o princípio da dignidade da pessoa humana.

Nesse sentido, disciplina Maria Celina Bodin de Moraes:

\begin{abstract}
"Sob esta ótica, as normas de direito civil necessitam ser interpretadas como reflexo das normas constitucionais. A regulamentação da atividade privada (porque regulamentação da vida quotidiana) deve ser, em todos os seus momentos, expressão da indubitável opção constitucional de privilegiar a dignidade da pessoa humana (...). Tais são os fundamentos daquilo que se começa a delinear como a fundação de um "direito civil constitucionalizado", um direito civil efetivamente transformado pela normativa constitucional"3.
\end{abstract}

\footnotetext{
${ }^{2}$ TEPEDINO, Gustavo. Premissas metodológicas para a constitucionalização do direito civil. In: TEPEDINO, Gustavo. Temas de Direito Civil, Rio de Janeiro: Renovar, 2004, p. 13.

${ }^{3}$ BODIN DE MORAES, Maria Celina. A caminho de um direito civil constitucional. Direito, Estado e Sociedade: Revista do Departamento de Direito da PUC-Rio, n. 1, 2. ed.. Rio de Janeiro: PUC-Rio, jul./dez. 1991, p. 68.
} 
A atividade hermenêutica da doutrina civil-constitucional determina, portanto, a releitura do direito civil à luz dos princípios emanados da Constituição, privilegiando os valores existenciais, com foco especialmente na proteção da dignidade da pessoa humana.

Ademais, o processo de constitucionalização do direito pôs fim definitivamente à separação entre direito público e direito privado, determinando a aplicação dos princípios fundamentais consagrados na Carta Constitucional às relações entre particulares.

\section{2) A superação da dicotomia entre direito público e direito privado}

Em decorrência do fenômeno de constitucionalização do direito, foi totalmente superada a dicotomia anteriormente existente entre direito público e direito privado, não havendo mais como definir precisamente o campo de atuação de cada uma dessas esferas jurídicas.

Com deslocamento do eixo central do sistema jurídico para a Constituição e a necessidade de adequação de todo o ordenamento aos valores constitucionais, ocorreu uma verdadeira interpenetração entre o direito público e o direito privado, colocando fim à antiga demarcação dos territórios de aplicação de tais normas. Assim, não há mais como estabelecer exatamente quais são as áreas de atuação de cada ramo do direito, em razão dessa incidência mútua dos institutos jurídicos públicos e privados.

É possível apenas aferir o interesse público ou privado predominante em cada instituto, mas não poderá somente um deles ser exclusivamente considerado. É o que a doutrina chama de distinção meramente quantitativa entre direito público e direito privado. Nas palavras de Gustavo Tepedino:

"[...] pode-se provavelmente determinar os campos do direito público ou do direito privado pela prevalência do interesse público ou do interesse privado, não 
já pela inexistência de intervenção pública nas atividades de direito privado ou pela exclusão da participação do cidadão nas esferas da administração pública" ${ }^{4}$.

Com a Constituição Federal de 1988 e a elevação da dignidade da pessoa humana a fundamento da República, essa visão ficou ainda mais consolidada, devendo todo o sistema jurídico ser informado pelos princípios e normas constitucionais.

Dessa maneira, os valores consagrados na nova Constituição passaram a ser a linha condutora de todo o ordenamento jurídico infraconstitucional, independentemente da sua natureza pública ou privada. Mesmo os institutos jurídicos patrimoniais, que se referem apenas às relações entre particulares, não estão mais imunes à incidência das normas constitucionais, visto que os princípios fundamentais não vinculam apenas o poder público, aplicando-se, também, à esfera privada.

Como afirma Luís Roberto Barroso, a constitucionalização do direito civil também repercutiu nas relações entre particulares, estabelecendo limitações à autonomia da vontade, através da imposição de restrições à liberdade de contratar e ao uso da propriedade privada, subordinando tais institutos aos valores constitucionais e ao respeito aos direitos fundamentais 5 .

Do mesmo modo, o respeito à dignidade da pessoa humana se aplica às relações privadas, determinando a proteção dos sujeitos vulneráveis, que se situam em uma posição de inferioridade, garantindo-lhes certas prerrogativas e direitos. É o caso, por exemplo, das crianças, dos incapazes, dos idosos, dos hipossuficientes e dos consumidores, que passaram a ser tutelados de modo prioritário pelo direito civil constitucionalizado.

Assim, entende-se que a constitucionalização do direito e a elevação da pessoa humana ao ponto mais alto da ordem constitucional brasileira

\footnotetext{
${ }^{4}$ TEPEDINO, Gustavo. Premissas metodológicas para a constitucionalização do direito civil. Op. Cit., p. 20.

${ }^{5}$ BARROSO, Luis Roberto. Op.Cit., p. 12 e 13.
} 
promoveram, no âmbito do direito civil, a sua "despatrimonialização", vez que os valores existenciais assumiram posição de destaque nas normas privadas, em detrimento do sistema patrimonialista antes predominante. Como ensina Rose Melo Vencelau:

"[...] o direito civil constitucionalizado impõe a releitura dos institutos de direito civil à luz dos valores constitucionais, sobretudo, a dignidade da pessoa humana, o que traz como conseqüência a posição da pessoa humana no centro da disciplina civilista, mesmo quando se tiver diante de situações tradicionalmente centradas no patrimônio. Assim, a chamada despatrimonialização do direito privado é corolário direto do direito civil-constitucional". 6

Desta feita, os valores constitucionais, principalmente a dignidade humana, tornaram-se diretrizes fundamentais na operacionalização de todos os institutos jurídicos, seja de direito público ou de direito privado. A pessoa humana consagrou-se como valor unificante do ordenamento jurídico, de maneira que todos os ramos do direito, independentemente da sua natureza, devem ser direcionados no sentido da sua promoção e proteção.

${ }^{6}$ VENCELAU, Rose Melo. Autonomia privada e dignidade humana. Rio de Janeiro: Renovar, 2009, p. 12. 


\section{2) Dignidade da Pessoa Humana e a Tutela da Personalidade}

\section{1) O princípio da dignidade da pessoa humana}

A dignidade da pessoa humana é o valor supremo da ordem constitucional brasileira, consagrado como fundamento da República e como cláusula geral de tutela da personalidade, no qual toda a ordem jurídica brasileira se apóia e se constrói. É o valor que dá unicidade valorativa e axiológica ao Direito, de onde irradiam os demais princípios fundamentais, constituindo um sistema integral de tutela da pessoa humana. Assim, o Estado existe em função da pessoa humana, já que o ser humano e sua proteção configuram a finalidade precípua da atividade estatal ${ }^{7}$.

Contudo, não há qualquer definição positivada de dignidade humana, uma vez que a legislação não prevê expressamente o seu conteúdo, suas características e o seu alcance. A Constituição se limitou a contemplar tal princípio, representado pelos valores enraizados na consciência coletiva da sociedade, anunciando os mecanismos protetivos da pessoa humana através de direitos e garantias fundamentais.

Verifica-se, então, que o princípio da dignidade da pessoa humana não é fruto de criação da ordem jurídica, mas, ao contrário, é um valor que antecede o Direito. Desta forma, antes de se conferir tutela jurídica à pessoa humana, foi necessário reconhecer o homem como sujeito de direitos e, consequentemente, como detentor de uma dignidade própria ${ }^{8}$. Ou seja, forçoso se fez aceitar a pessoa humana como titular de direitos apenas em razão da sua condição humana e da dignidade a ela inerente.

\footnotetext{
${ }^{7}$ SARLET, Ingo Wolfgang. Dignidade da pessoa humana e direitos fundamentais. Porto Alegre: Livraria do Advogado, 2006, p. 65.

${ }^{8}$ BODIN DE MORAES, Maria Celina. Danos à pessoa humana. Uma leitura civil-constitucional do dano moral. Rio de Janeiro: Renovar, 2004, p. 82.
} 
Por isso, entende-se que o desenvolvimento da expressão jurídica da dignidade humana se deu pelo recurso à filosofia, principalmente aos postulados morais kantianos. Segundo o Imperativo Categórico de Kant, uma conduta somente será considerada moral se a máxima do seu agir puder ser transformada em lei universal. Assim, o filósofo não estabelece um rol de deveres morais, mas prevê um imperativo categórico que permite aos indivíduos avaliar as máximas de suas condutas para verificar se elas podem ser alçadas à categoria de lei universal, possuindo, portanto, caráter moral.

As formulações de Kant são baseadas em três postulados: "age como se a máxima de tua ação devesse ser erigida por tua vontade em lei universal da natureza", "age de tal maneira que sempre trates a humanidade, tanto na tua pessoa como na pessoa de outrem, como um fim e nunca como um meio" e "age como se a máxima de tua ação devesse servir de lei universal para todos os seres racionais". 9

Ademais, Kant afirma que existem duas categorias de valores: o preço, relacionado aos bens materiais, que podem ser economicamente mensurados; e a dignidade, qualidade própria das pessoas, que representa um valor moral de interesse geral.

O filósofo constrói o entendimento de que o ser humano nunca pode ser visto como um meio para atingir objetivos diversos, devendo sempre ser considerado como um fim em si mesmo. Nesse sentido, o homem não pode ser economicamente avaliado, eis que dotado de uma dignidade intrínseca à condição humana.

No Brasil, acompanhando a tendência mundial e como forma de fortalecer o processo de redemocratização política do país, a dignidade da pessoa humana foi contemplada na Constituição Federal de 1988 como um dos fundamentos do Estado Democrático de Direito. Tal princípio foi

\footnotetext{
${ }^{9}$ BODIN DE MORAES, Maria Celina. O Princípio da dignidade humana. In: BODIN DE MORAES, Maria Celina (Coord.). Princípios do direito civil contemporâneo. Rio de Janeiro: Renovar, 2006, p. 11.
} 
elevado ao ápice do ordenamento constitucional brasileiro, sendo considerado como valor supremo e fundante de todo o sistema jurídico, social e político do país.

Com o processo de constitucionalização do direito, a importância da dignidade da pessoa humana tomou grandes proporções na ordem jurídica brasileira, sendo considerada como elemento fundamental na interpretação e aplicação de todos os ramos do Direito. No entanto, tendo em vista a extensa gama de conotações que tal princípio pode assumir, bem como a porosidade do conceito, faz-se necessário delimitar o seu contorno e seu alcance, sob pena de total abstratização e generalização da sua aplicação.

Procurando concretizar essa tarefa, Maria Celina Bodin de Moraes, valendo-se dos postulados filosófico kantianos, extraiu a essência do princípio da dignidade da pessoa humana:

"O substrato material da dignidade desse modo entendida pode ser desdobrado em quatro postulados: i) o sujeito moral (ético) reconhece a existência dos outros como sujeitos iguais a ele; ii) merecedores do mesmo respeito à integridade psicofísica de que é titular; iii) é dotado de vontade livre, de autodeterminação; iv) é parte do grupo social em relação ao qual tem a garantia de não vir a ser marginalizado". ${ }^{10}$

Assim, entende-se que a dignidade da pessoa humana se desdobra em quatro aspectos fundamentais: igualdade, integridade psicofísica, liberdade e solidariedade. É possível afirmar, portanto, que a dignidade humana foi consagrada pela doutrina como uma cláusula geral de tutela da personalidade, assegurando a proteção da pessoa humana em todos os seus aspectos.

\section{2) A dignidade da pessoa humana como cláusula geral de tutela da personalidade.}

Durante a vigência do liberalismo jurídico, sob a influência do pensamento burguês individualista e patrimonialista, o direito civil, baseado na propriedade privada e no contrato, era voltado primordialmente para a

\footnotetext{
${ }^{10}$ BODIN DE MORAES, Maria Celina. Danos à pessoa humana. Op. Cit., p. 85.
} 
tutela do indivíduo, considerado como sujeito de direitos e titular de um patrimônio, ao qual deveria ser garantida total autonomia para contratar. Os indivíduos eram absolutamente livres para regular os seus interesses particulares, preservando-se a esfera econômica da intervenção do poder público, de modo a construir um sistema de livre circulação de bens e riquezas.

O homem era visto como um ser bastante em si mesmo, uma microcélula autônoma, auto-suficiente e auto-subsistente ${ }^{11}$, desvinculado do restante da sociedade (homo clausus). Por isso, privilegiava-se o individualismo, o domínio e a transferência de riquezas, garantindo plena autonomia privada patrimonial.

Essa perspectiva durou até o século $\mathrm{XX}$, quando houve uma mudança radical do paradigma. As duas Guerras Mundiais e, principalmente, os massacres cometidos pelo nazismo alemão conduziram à necessidade de reconstrução dos direitos humanos e de criação de institutos jurídicos de valorização e proteção da pessoa. O mundo pós-guerra clamava pela criação de regras e princípios dedicados a salvaguardar o ser humano e sua dignidade.

Houve, portanto, a substituição do ponto de vista liberal, individualista e patrimonialista do século XIX, por uma visão humanista, voltada para o amparo da pessoa humana. O foco central dos ordenamentos jurídicos deslocou-se da tutela da autonomia privada para a proteção da pessoa humana, tornando-se necessário proteger não somente a esfera patrimonial, mas também a esfera da personalidade, manifestada através da identidade, integridade, privacidade e intimidade.

Em decorrência desse processo, a tutela da pessoa humana foi inserida na ordem constitucional de diversos países europeus. Em 1948, a Declaração Universal dos Direitos Humanos dispunha que "todas as

\footnotetext{
${ }^{11}$ BODIN DE MORAES, Maria Celina. O princípio da solidariedade. In: PEIXINHO, Manoel Messias; GUERRA, Isabella Franco; FILHO, Firly Nascimento (orgs.). Os princípios da Constituição de 1988. Rio de Janeiro: Lumen Juris, 2001, p.159.
} 
pessoas nascem livres e iguais em dignidade e direito". Por sua vez, a Constituição italiana de 1947 enunciou que "todos os cidadãos têm a mesma dignidade e são iguais perante a lei”, enquanto que a Constituição portuguesa de 1976 definia como base da República soberana de Portugal a dignidade da pessoa humana. Por fim, a Constituição Espanhola de 1978, estabeleceu que "a dignidade da pessoa, os direitos invioláveis que lhe são inerentes, o livre desenvolvimento da personalidade, o respeito à lei e aos direitos dos demais são fundamentos da ordem política e da paz social". ${ }^{12}$

Verifica-se, portanto, que a nova principiologia emergente no século XX foi adotada pela ordem constitucional de diversos países europeus, que passaram a conferir proteção à pessoa humana e à esfera existencial da personalidade.

A mudança paradigmática ocorrida no século XX também refletiu no ordenamento jurídico brasileiro, determinando a alteração das diretrizes constitucionais. Essa transformação é verificada, principalmente, com o advento da Constituição Federal de 1988, que em seu artigo $1^{\circ}$, inciso III, elevou o princípio da dignidade da pessoa humana ao status de fundamento da República Federativa do Brasil.

Com isso, a nova ordem constitucional passou a dar primazia para as questões de caráter existencial, em detrimento das relações de cunho patrimonial. A pessoa humana foi colocada no eixo central do ordenamento jurídico, e a preocupação pela sua proteção irradiou-se por todos os ramos do direito ${ }^{13}$.

Nesse sentido, o Código Civil de 2002, seguindo a mesma direção da Constituição, promoveu a ampliação do conceito de personalidade, de maneira a abranger também a sua dimensão existencial. Assim, a

\footnotetext{
${ }^{12}$ Informações obtidas em BODIN DE MORAES, Maria Celina. Danos à pessoa humana. Op. Cit., p. 82.

${ }^{13}$ Afirma Rose Melo Vencelau: “[...] as situações jurídicas subjetivas existenciais prevalecem sobre as patrimoniais em hipótese de conflito, pois naquelas, em primeiro plano, se exprime o ser e o agir da pessoa humana" (VENCELAU, Rose Melo. Autonomia privada e dignidade humana Op. Cit., p. 9)
} 
personalidade não pode ser reduzida apenas à sua esfera patrimonial, considerada exclusivamente como capacidade de titularizar direitos e contrair obrigações (artigo $2^{\circ}$ do Código Civil), sendo necessário abarcar todo o conjunto de atributos e características inerentes à condição humana, para que seja protegido, acima de tudo, o seu valor existencial. A pessoa é merecedora de tutela jurídica pelo simples fato de ser humana e não por titularizar bens e direitos.

Para efetivar a proteção da personalidade, o Código Civil de 2002 inovou, dedicando um capítulo inteiro para a sua regulamentação. Os artigos 11 a 21 proclamam os direitos da personalidade, assim enumerados como o direito à integridade física, ao nome, à imagem, à honra e à privacidade.

No entanto, diversas críticas doutrinárias foram elaboradas contra a regulação dos direitos da personalidade pelo Código Civil. Uma delas se refere à técnica adotada para a tutela da personalidade, que, por reduzi-la à categoria de direitos subjetivos, torna-se muito semelhante aos moldes de proteção dos direitos patrimoniais. Foram utilizados os mesmos instrumentos de tutela da propriedade para a proteção da personalidade, o que limitou o seu alcance e minimizou a sua importância.

O direito subjetivo é o poder jurídico conferido pela lei para a satisfação de um interesse próprio, contraposto a um dever jurídico, que se não for cumprido, enseja para o titular do direito, a pretensão de exigir o cumprimento da obrigação ${ }^{14}$. Verifica-se, então, que se trata de uma categoria jurídica voltada para a regulamentação das relações patrimoniais.

Conforme explicita Pietro Perlingieri, não existe, no âmbito da personalidade, dualidade entre sujeito e objeto, vez que a pessoa humana reveste tanto a condição de titular do direito quanto de objeto de proteção ${ }^{15}$. Desse modo, o modelo de tutela baseado no direito subjetivo torna-se

\footnotetext{
${ }^{14}$ NÁUFEL, José. Novo dicionário jurídico brasileiro. Rio de Janeiro: Forense, 2008, p. 350.

${ }^{15}$ PERLINGIERI, Pietro. Perfis de direito civil. Rio de Janeiro: Renovar, 1999, p. 155.
} 
insuficiente para atender todas as possíveis situações jurídicas subjetivas que reclamam proteção.

Entende-se, portanto, que a personalidade é um valor que se perfaz por meio de diversas situações jurídicas subjetivas, podendo se manifestar não somente através do direito subjetivo, mas também como poder jurídico, direito potestativo, autoridade parental, interesse legítimo, faculdade, pretensão, ou qualquer outra situação jurídica relevante ${ }^{16}$.

Por outro lado, o sistema de tipificação dos direitos da personalidade no Código Civil também foi alvo de críticas, tendo em vista que a proteção da pessoa humana não se esgota no rol taxativo previsto pelo legislador civilista. Os direitos da personalidade não podem ser reduzidos a um número limitado de situações definidas em lei, devendo ser ela protegida em todas as situações existenciais em que a pessoa humana estiver envolvida, independentemente de previsão legal.

Com os constantes progressos científicos e tecnológicos e o consequente surgimento de novos fatos sociais, torna-se cada vez mais difícil que a lei acompanhe a evolução dinâmica das mudanças cotidianas. Assim, face à impossibilidade de definição legal de todas as possíveis situações jurídicas nas quais pode haver a manifestação da personalidade, verifica-se que esse sistema de tipificação não assegura à pessoa humana uma ampla proteção.

Sintetizando o até aqui exposto, afirma Pietro Perlingieri:

“A personalidade, portanto, não é um direito, mas sim, um valor (o valor
fundamental do ordenamento) e está na base de uma série aberta de situações
existenciais, nas quais se traduz a sua incessantemente exigência mutável de
tutela. Tais situações subjetivas não assumem necessariamente a forma do direito
subjetivo e não devem fazer com que se perca de vista a unidade do valor
envolvido. Não existe um número fechado de hipóteses tuteladas: tutelado é o

${ }^{16}$ BODIN DE MORAES, Maria Celina. Ampliando os direitos da personalidade. In: José Ribas Vieira. (Org.). 20 anos da Constituição cidadã de 1988: efetivação ou impasse institucional?. Rio de Janeiro: Forense, 2008, p. 372 e 373. 
valor da pessoa sem limites, salvo aqueles colocados no seu interesse e naqueles de outras pessoas". ${ }^{17}$

Há que se considerar, portanto, a elasticidade da proteção da personalidade, devendo ela abranger todas as situações em que estiver envolvida a pessoa humana e não apenas os casos tipificados pela lei civil. Somente seria legítimo ao legislador restringir as garantias individuais asseguradas pela Constituição se tal situação fosse justificada e autorizada pela própria dignidade da pessoa humana.

Da mesma maneira, a proteção da pessoa humana requer mais do que a tutela meramente negativa e patológica promovida pelo Código Civil, consubstanciada por meio de técnicas repressivas e ressarcitórias, que asseguram ao titular a possibilidade de ser indenizado em virtude de uma lesão sofrida a um de seus direitos extrapatrimoniais. Devem ser conferidos instrumentos de promoção da personalidade, a serem exercitados independentemente de violação à esfera subjetiva, de maneira a garantir também uma tutela positiva da pessoa humana.

Diante de tais críticas, verifica-se que o sistema de proteção da personalidade pelo Código Civil se revela insuficiente para a tutela e promoção da pessoa humana, devendo ele, portanto, ser contextualizado à luz da Constituição Federal.

Nesse sentido, sob a ótica da doutrina civil constitucional, a elevação da dignidade da pessoa humana ao status de fundamento da República (artigo $1^{\circ}$, inciso III) consagrou a cláusula geral de tutela e promoção da personalidade, alçando a pessoa humana e o livre desenvolvimento da sua personalidade à condição de valor máximo do ordenamento jurídico brasileiro $^{18}$.

\footnotetext{
${ }^{17}$ PERLINGIERI, Pietro. O direito civil na legalidade constitucional. Rio de Janeiro: Renovar: 2008, p. 764.

${ }^{18}$ Em relação ao direito italiano, Pietro Perlingieri afirma que: "O art. 2 Const. é uma norma diretamente aplicável e exprime uma cláusula geral de tutela da pessoa humana: o seu conteúdo não se limita a resumir os direitos tipicamente previstos por outros artigos da Constituição, mas
} 
A criação dessa cláusula geral de tutela da personalidade permite a percepção da pessoa humana como valor central da ordem jurídica. A proteção da personalidade pelo Código Civil deve ser, portanto, interpretada e apreendida sob a lente da Constituição Federal, de maneira a realizar os valores nela consagrados, tutelando integralmente a pessoa humana e sua dignidade.

Neste diapasão, há que se considerar que a tutela da personalidade garantida constitucionalmente através da dignidade da pessoa humana não se aplica apenas às relações entre o poder público e os indivíduos, como forma de amparo destes contra os arbítrios estatais. Face à superação da dicotomia entre direito público e direito privado, a cláusula geral de proteção da personalidade deve ser respeitada, também, nas relações entre particulares, sejam elas patrimoniais ou existenciais.

Diante dessa nova perspectiva e tendo em vista a constitucionalização do direito, alguns institutos clássicos do direito privado tiverem seu conteúdo reformulado. É o caso, por exemplo, da autonomia privada, que passou a ser concebida não apenas pelo viés patrimonial, mas também sob a ótica das relações jurídicas existenciais. Desse modo, entende-se que a vontade individual está vinculada à proteção integral da dignidade da pessoa humana, devendo, portanto, ser considerada enquanto promover o livre desenvolvimento da personalidade.

\section{3) Autonomia privada patrimonial e existencial}

O conceito de autonomia privada vigente no liberalismo jurídico do século XVIII dizia respeito somente à esfera patrimonial: os indivíduos, dotados de auto-determinação e autorregulamentação, detinham plena liberdade de contratar e poder de livre disposição sobre seus bens e direitos patrimoniais, independentemente das finalidades e intenções.

permite estender a tutela a situações atípicas". (PERLINGIERI, Pietro. Perfis de direito civil. Op. Cit., p.155). 
A ideologia burguesa e o modelo de produção capitalista eram calcados na propriedade e no contrato, esferas sobre as quais os indivíduos exerciam completa autonomia. Nesse contexto, os Códigos Oitocentistas (inclusive o Código Civil brasileiro de 1916) garantiam total liberdade econômica aos indivíduos, que podiam regular seus interesses patrimoniais de forma absolutamente autônoma. Não havia, portanto, qualquer forma de intervenção do Estado na propriedade e na economia, face à total divisão entre o direito público e o direito privado.

Com a mudança paradigmática ocorrida no século XX, foi necessária a redefinição da autonomia privada à luz da dignidade da pessoa humana. A constitucionalização do direito civil e a consequente superação da dicotomia entre direito público e privado, somados à aplicação dos princípios constitucionais na esfera das relações particulares, determinaram a alteração do foco de proteção da propriedade para a personalidade. Assim, a antiga visão patrimonialista da autonomia privada não encontrou espaço no quadro contemporâneo, tendo que se adequar às novas diretrizes constitucionais.

Desse modo, considerando que os princípios constitucionais orientam o ordenamento jurídico no sentido da tutela da personalidade, o Código Civil deixa de ser meramente regulador dos aspectos patrimoniais, para proteger, também, os interesses existenciais da pessoa humana. Ocorre, com isso, a chamada "despatrimonialização do direito civil", como conseqüência do seu processo de constitucionalização.

Diante dessa perspectiva civil-constitucional e tendo em vista os princípios consagrados na Constituição Federal de 1988, o conceito de autonomia é reformulado para abranger, também, a proteção dos espaços de liberdade relativos à existência ${ }^{19}$. Surge, assim, a autonomia privada existencial, ou seja, a capacidade de autodeterminação, o poder de realizar

\footnotetext{
${ }^{19}$ DALSENTER, Thamis. Corpo e autonomia: a interpretação do artigo 13 do Código Civil brasileiro. Rio de Janeiro. 2009. Tese (Mestrado em Direito) - Departamento de Direito da PUC Rio. p. 72
} 
as próprias escolhas individuais, o próprio projeto de vida, de modo a promover o livre desenvolvimento da personalidade.

No entanto, o Código Civil de 2002, ao regular os direitos da personalidade, restringiu a autonomia privada dos indivíduos em relação às situações existenciais. Com isso, o legislador proibiu a limitação voluntária dos direitos da personalidade, tornando-os indisponíveis. Neste sentido, preceitua o artigo 11:

"Art. 11. Com exceção dos casos previstos em lei, os direitos da personalidade são intransmissíveis e irrenunciáveis, não podendo seu exercício sofrer limitação voluntária".

A doutrina discorda da regulamentação das relações extrapatrimoniais dada pelo Código Civil, entendendo que, para a concretização da dignidade da pessoa humana, o ordenamento jurídico deveria garantir maior liberdade de escolha aos indivíduos no que tange aos seus direitos existenciais.

Maria Celina Bodin de Moraes, ao criticar o dispositivo legal acima citado, indaga se:

“[...] em virtude do mesmo princípio fundamental da proteção da dignidade humana, não derivaria, logicamente, uma expansão da autonomia privada no que se refere às escolhas da vida privada de cada pessoa humana? Ou seja, a privacidade garantida pela Constituição a uma pessoa digna, plenamente capaz, não deveria significar, pelo menos em linha de princípio, mais amplo poder de escolha sobre os seus bens mais importantes?". ${ }^{20}$

Tentando compatibilizar tal dispositivo com os princípios constitucionais, principalmente a dignidade da pessoa humana, a doutrina civilista brasileira aprovou dois Enunciados nas Jornadas de Direito Civil do Conselho da Justiça Federal ${ }^{21}$, no sentido de relativizar a proibição de limitação voluntária dos direitos da personalidade. Percebe-se, claramente,

\footnotetext{
${ }^{20}$ BODIN DE MORAES, Maria Celina. Ampliando os direitos da personalidade. Op. Cit. p. 371.

${ }^{21}$ Enunciado $\mathrm{n}^{\mathrm{0}} .4$ da I Jornada: "O exercício dos direitos da personalidade pode sofrer limitação voluntária, desde que não seja permanente nem geral".

Enunciado $n^{\circ} .139$ da III Jornada: "Os direitos da personalidade podem sofrer limitações, ainda que não especificamente previstas em lei, não podendo ser exercidos com abuso de direito de seu titular, contrariamente à boa-fé objetiva e aos bons costumes".
} 
que o entendimento doutrinário segue a direção oposta do texto legal, permitindo uma maior expansão da autonomia privada no que tange aos aspectos extrapatrimoniais dos indivíduos.

Assim, a interpretação de tal dispositivo deve ser feita de maneira a se obter a coexistência harmônica entre a indisponibilidade dos direitos da personalidade e a tutela da autonomia privada existencial, de modo a ser assegurada a inviolabilidade da vida privada, direito fundamental previsto pelo artigo $5^{\circ}$, inciso $\mathrm{X}$ da Constituição Federal.

Importa considerar, inclusive, que a autonomia privada existencial se configura como instrumento de livre desenvolvimento da personalidade, caracterizando, portanto, uma forma de tutela positiva da pessoa humana. Assim, deve ser assegurada aos indivíduos ampla liberdade de autodeterminação dos seus interesses extrapatrimoniais, de modo a haver a realização da dignidade humana, através da promoção e manifestação da personalidade.

Então, é possível afirmar que a extrema regulamentação dos aspectos existenciais prejudica a exaltação da identidade pessoal, pelo que deve haver um campo maior de livre atuação individual, no qual a intervenção do Estado seja feita de maneira protetiva e não apenas restritiva, a fim de que a privacidade seja resguardada e a personalidade possa se desenvolver. Assim afirma Thamis Dalsenter:

"[...] a imposição generalizante de que os direitos da personalidade são indisponíveis, não importando para tanto circunstâncias subjetivas ou objetivas, é relativizada para que o desenvolvimento da personalidade seja um espaço de viver livre e criativo, ou seja, um campo onde as escolhas de vida feitas pelas pessoas são protegidas pela privacidade".

Conclui-se, portanto, que a onipresença do Direito não pode se agigantar de tal modo a sufocar todos os espaços de liberdade, sendo necessário deixar a vida privada à livre escolha dos indivíduos. Ou seja, o Estado não pode intervir tão intensamente na esfera particular das pessoas,

\footnotetext{
${ }^{22}$ DALSENTER, Thamis. Op. cit., p. 146.
} 
devendo garantir-lhes autonomia, a fim de que haja o livre desenvolvimento da sua personalidade.

Nessa zona de atuação da liberdade individual e de proteção da privacidade está inserida a autonomia corporal, considerando-se o corpo como um espaço para a manifestação da personalidade e da identidade do seu titular. Desse modo, a tutela da integridade psicofísica deve levar em consideração as próprias escolhas dos indivíduos, a liberdade de definir o seu destino, a fim de que seja realizada a dignidade da pessoa humana. 


\section{3) Atos de Disposição sobre o Próprio Corpo}

\section{1) Interpretação civil-constitucional do artigo 13 do Código Civil}

O artigo 13 do Código Civil, ao enunciar o direito à integridade física, apresenta limites à autonomia corporal:

\footnotetext{
"Art. 13. Salvo por exigência médica, é defeso o ato de disposição do próprio corpo, quando importar diminuição permanente da integridade física ou contrariar os bons costumes.

Parágrafo único: $O$ ato previsto neste artigo será admitido para fins de transplante, na forma estabelecida em lei especial”.
}

Pela leitura do mencionado dispositivo, verifica-se que o Código Civil brasileiro somente admite os atos de disposição sobre o próprio corpo quando não houver diminuição permanente da integridade física, nem violação dos bons costumes, com exceção apenas dos atos justificados pela exigência médica.

Portanto, estamos diante de uma norma fechada, que não permite a análise do merecimento de tutela do interesse do disponente em cada caso concreto, estabelecendo apenas limites rígidos e estáticos à disponibilidade corporal. $^{23}$

Todavia, em função da constitucionalização do direito civil, tais limites devem ser interpretados à luz dos princípios constitucionais, tendo como diretriz fundamental a dignidade da pessoa humana, de modo que a tutela jurídica do corpo não seja apenas um campo de restrição da autonomia, mas também uma garantia da liberdade de autodeterminação corporal.

A respeito da proibição de diminuição permanente da integridade física, entende-se que a proteção legal deve abranger tanto a esfera física quanto psíquica dos indivíduos, tendo em vista a inseparabilidade entre o

\footnotetext{
${ }^{23}$ VENCELAU, Rose Melo. Autonomia privada e dignidade humana. Op. Cit., p. 184.
} 
corpo e a mente. Assim, a melhor interpretação desse parâmetro previsto no artigo 13 é no sentido de haver, sempre que possível, a coexistência harmônica entre essas duas esferas, baseada na proteção integral da dignidade da pessoa humana.

Os bons costumes, segundo limite imposto pelo dispositivo em análise, é tradicionalmente conceituado como conjunto de regras de convivência estabelecidas socialmente, que traduzem a realidade objetiva da moral social. Assim, o exercício de um direito apresenta-se contrário aos bons costumes quando tiver conotações de imoralidade ou de violação das normas elementares impostas pelo decoro social. ${ }^{24}$

Tal conceito deve ser, contudo, interpretado sob a ótica do ordenamento democrático pluralista. Nesse sentido, através de uma leitura constitucionalizada, o termo "bons costumes" deve ser entendido como a moralidade constitucional, em consonância com os princípios fundamentais da República, principalmente a dignidade da pessoa humana ${ }^{25}$. Conclui-se, portanto, que são "valores compartilhados que ultrapassam limites setoriais, ou seja, que não expressam valores de uma moralidade privada, ainda que esta seja majoritária". ${ }^{26}$

Por fim, o último critério previsto no artigo 13 autoriza os atos de disposição sobre o corpo justificados pela exigência médica. Esse critério é considerado como hierarquicamente superior aos demais, uma vez que é capaz de legitimar a diminuição da integridade física e a violação dos bons costumes para assegurar o restabelecimento da saúde do paciente e, com isso, preservar a sua dignidade. É esse o pressuposto que autoriza a cirurgia

\footnotetext{
${ }^{24}$ COSTA, Mário Júlio de Almeida. Direito das obrigações. $8^{a}$ ed., Coimbra: Almedina, 2000, p. 76. Apud RODRIGUES JÚNIOR, Álvaro. A recusa ao pagamento de indenização por invalidez total em contrato de seguro e o abuso de direito. Disponível em: <http://www.buscalegis.ccj.ufsc.br/revistas/index.php/buscalegis/article/viewFile/9790/9356>. Acessado em 20 set. 2010.

25 "Em uma sociedade pluralista, que protege constitucionalmente os mais diversos estilos de vida e preconiza a tolerância e a não-discriminação, torna-se tarefa de difícil justificação a proibição de atos individuais que não atinjam terceiro, sob o fundamento da violação dos "bons costumes". (TEPEDINO, Gustavo, et. al. Código Civil interpretado conforme a Constituição da República. Rio de Janeiro: Renovar, 2007, vol. I, p. 37).

${ }^{26}$ DALSENTER, Thamis. Op. Cit., p. 117.
} 
de transgenitalização no ordenamento jurídico brasileiro, em razão da sua finalidade terapêutica justificada pela inadequação entre o sexo físico e o sexo psicológico, conforme será analisado a seguir.

Diante do exposto, conclui-se que os limites impostos pelo artigo 13 do Código Civil aos atos de disposição sobre o próprio corpo devem ser lidos sob a ótica dos princípios constitucionais, tendo como escopo principal a proteção da dignidade da pessoa humana. Nesse sentido, deve ser assegurada autonomia corporal aos indivíduos, a fim de promover o desenvolvimento da sua personalidade.

\section{2) Autonomia corporal e a tutela da integridade psicofísica.}

A autonomia corporal pode ser entendida como a capacidade de autodeterminação da pessoa em relação ao seu próprio corpo, estando, portanto, inserida na esfera das situações existenciais ${ }^{27}$. Trata-se da liberdade do indivíduo para dispor sobre o próprio corpo ou sobre partes dele, determinando o seu destino de acordo com suas convicções e anseios pessoais.

Nesse ponto, faz-se necessário tecer comentários acerca do direito à integridade psicofísica, tido como um dos desdobramentos da dignidade da pessoa humana.

Inicialmente, cumpre verificar a indissociabilidade entre corpo e mente, de modo que a tutela deve ser destinada tanto à esfera física, quanto psíquica dos indivíduos. ${ }^{28}$ Nesse sentido dispõe o Enunciado $\mathrm{n}^{\circ}$. 6 da I Jornada de Direito Civil do Conselho da Justiça Federal ao afirmar que "a expressão exigência médica, contida no art. 13, refere-se tanto bem-estar físico quanto ao bem-estar psíquico do disponente”.

\footnotetext{
${ }^{27}$ DALSENTER, Thamis. Op. Cit., p. 72.

28 De acordo com Pietro Perlingieri, "Seja o perfil físico, seja o perfil psíquico, ambos constituem componentes indivisíveis da estrutura humana. A tutela de um destes perfis traduz-se naquela da pessoa no seu todo, e disciplina na qual consiste esta tutela é, de regra, utilizável também para cada um de seus aspectos" (PERLINGIERI, Pietro. Perfis de direito civil. Op. Cit., p.158).
} 
Ademais, no que tange à sua proteção, tradicionalmente, a integridade física era apenas protegida no âmbito do direito penal, através da vedação à tortura e penas cruéis. Em decorrência do fenômeno da despatrimonialização do direito civil e a alteração do foco central do ordenamento jurídico para a pessoa humana, a integridade foi consagrada como objeto de proteção também no âmbito cível.

Surge, então, um sistema dúplice de tutela do corpo: de um lado, é protegido contra a atuação de terceiros, devendo ser penalizada criminalmente qualquer tipo de ofensa a integridade física ${ }^{29}$; por outro lado, o corpo passou ser protegido contra atuações ofensivas de seu próprio titular.

Os avanços médicos e tecnológicos fazem surgir questões a respeito dos limites acerca da autonomia corporal. Em que circunstâncias seriam lícitos os atos de disposição sobre o próprio corpo, tendo em vista a tutela da pessoa humana? Quais limites devem ser impostos à autodeterminação corporal?

O artigo 13 do Código Civil, ao regulamentar o direito à integridade física, preceitua:

"Art. 13. Salvo por exigência médica, é defeso o ato de disposição do próprio corpo, quando importar diminuição permanente da integridade física ou contrariar os bons costumes.

\footnotetext{
${ }^{29}$ Artigo 129 do Código Penal brasileiro tipifica os crimes de lesão corporal:

Art. 129. Ofender a integridade corporal ou a saúde de outrem:

Pena - detenção, de três meses a um ano.

$\S 1^{\circ}$ Se resulta:

I - Incapacidade para as ocupações habituais, por mais de trinta dias;

II - perigo de vida;

III - debilidade permanente de membro, sentido ou função;

IV - aceleração de parto:

Pena - reclusão, de um a cinco anos.

$\S 2^{\circ}$ Se resulta:

I - Incapacidade permanente para o trabalho;

II - enfermidade incurável;

III - perda ou inutilização do membro, sentido ou função;

IV - deformidade permanente;

V - aborto:

Pena - reclusão, de dois a oito anos.
} 
Parágrafo único: $\mathrm{O}$ ato previsto neste artigo será admitido para fins de transplante, na forma estabelecida em lei especial".

Verifica-se, portanto, que o dispositivo legal acima citado restringe a autonomia corporal, impondo limites aos atos de disposição sobre o corpo humano. São restrições de ordem genérica, que não levam em consideração o discernimento dos indivíduos e a sua capacidade de escolha. Assim, a pessoa somente pode dispor do seu próprio corpo quando não houver violação dos bons costumes e não causar diminuição permanente da integridade física, excepcionando apenas os casos autorizados pela exigência médica.

Ao dispor nesse sentido, o legislador civilista adotou uma postura paternalista em relação à autonomia corporal, reduzindo excessivamente a possibilidade de disposição sobre o próprio corpo.

O paternalismo jurídico é uma forma de intervenção do Estado na esfera privada, que, ao proibir determinados comportamentos, minimiza o direito à liberdade, sob o argumento de estar protegendo os indivíduos. O paternalismo se situa na máxima segundo a qual "as pessoas devem ser protegidas de si próprias", de modo que tudo deve ser proibido ou regulado, somente sendo possível fazer aquilo que é expressamente permitido. Por isso, entende-se que o paternalismo somente é compatível com as sociedades infantilizadas, irresponsáveis, ignorantes e inconsequentes, cujos indivíduos necessitam que o Estado tome as decisões por eles. ${ }^{30}$

O Estado Democrático de Direito brasileiro, concretizado por meio dos princípios constitucionais, não admite essa forma de intervenção paternalista, devendo prevalecer, em princípio, a liberdade e a vontade individual, para que seja assegurado o livre desenvolvimento da personalidade. A regulação estatal a respeito da autonomia corporal dos indivíduos deve, portanto, ser realizada de modo protetivo e não simplesmente restritivo.

\footnotetext{
${ }^{30}$ BODIN DE MORAES, Maria Celina. Ampliando os direitos da personalidade. Op. Cit. p. 379.
} 
Porém, os limites abstratos e genéricos previstos no artigo 13 do Código Civil não deixam espaço para identificar as hipóteses em que o exercício do direito ao próprio corpo é legítimo, bem como os casos em que a autodeterminação corporal deve ser suprimida. Assim, em nome da autonomia existencial e como forma de refutar a excessiva intervenção do Estado na esfera privada, deve-se analisar a capacidade e o discernimento dos indivíduos para avaliar os limites da autonomia corporal.

Esse entendimento deve vigorar até mesmo em relação aos atos acráticos, isto é, atos aparentemente irracionais praticados voluntária e conscientemente por pessoas capazes e dotadas de discernimento ${ }^{31}$. O sujeito opta por praticar tais atos, mesmo sabendo dos seus riscos e de eventuais prejuízos que poderão causar.

É o caso, por exemplo, das Testemunhas de Jeová que se recusam a receber uma transfusão de sangue indispensável à manutenção das suas vidas, por motivos de ordem religiosa. Nessa hipótese, tendo em vista que ordenamento constitucional democrático preconiza o pluralismo e o respeito à diferença, entende-se ser legítima a recusa, desde que o paciente adepto de tal corrente religiosa tenha capacidade e discernimento suficientes para manifestar sua vontade nesse sentido, responsabilizando-se pelas consequências de tal ato.

Assim, o paternalismo deve ser mitigado em virtude da liberdade de crença, direito fundamental assegurado constitucionalmente. Entende-se que há um conflito de valores existenciais, devendo prevalecer, nesse caso, os direitos à privacidade, à autodeterminação do corpo e à liberdade religiosa.

\footnotetext{
${ }^{31}$ Nesse sentido, entende Ronald Dworkin: "we should respect the decisions people make for themselves, even when we regard theses decisions as imprudent, because each person generally knows what is in own best interest better than anyone else". (DWORKIN, Ronald. Life's dominion. p. 223. Apud VENCELAU, Rose Melo. Apontamentos sobre o papel da vontade nas situações jurídicas existenciais. Revista Trimestral de Direito Civil - RTDC, n.25, jan./mar.2006, p. 240).
} 
Ademais, em razão da indissociabilidade entre corpo e mente, uma eventual restrição à autonomia corporal com o objetivo de preservar a integridade física, impondo a realização da transfusão, acarretaria graves consequiências à esfera psíquica dessas pessoas e, fatalmente, violaria a sua dignidade. Considerando que as Testemunhas de Jeová possuem visões distintas a respeito do conceito de vida digna, nesses casos, a concretização do princípio da dignidade da pessoa humana somente será possível com o respeito à autonomia corporal ${ }^{32}$.

Essa liberdade de escolha não pode, contudo, atingir a esfera jurídica de terceiros, de modo que não poderia uma mãe Testemunha de Jeová recusar a transfusão de sangue em seu filho. A autodeterminação se limita ao corpo do próprio indivíduo, não podendo extrapolar tal barreira para determinar as escolhas em nome de terceiros.

Desta feita, para avaliar o alcance da autonomia corporal, é necessário analisar a capacidade e o discernimento, devendo ser ela assegurada quando o indivíduo gozar de aptidão jurídica para dispor sobre o seu próprio corpo e de capacidade de compreender e analisar a extensão da prática de tais atos, além de assumir a responsabilidade e suportar as suas consequências.

\footnotetext{
${ }^{32}$ Adota posicionamento contrário o Procurador do Estado do Rio de Janeiro, Flávio de Araújo Willeman, conforme pronunciamento em parecer normativo sobre o tema, requerido pelo Diretor Jurídico da Universidade do Estado do Rio de Janeiro - UERJ: “(i) a legislação pertinente não faculta às pessoas a disposição da própria vida por razões de ordem religiosa: (ii) as diretivas éticas dos Conselhos de Medicina obrigam os médicos a proceder ao tratamento necessário para salvar a vida do paciente, sem o seu consentimento ou a despeito da sua recusa; (iii) o Código Civil de 2002, "em franca interpretação autêntica da CRFB/88", determina a irrenunciabilidade dos direitos da personalidade, bem como a indisponibilidade do corpo humano; (iv) "o direito fundamental à vida humana deve ser considerado um direito universal quase que absoluto, não podendo ser relativizado e/ou flexibilizado para atender a culturas regionais, religiosas e/ou fundamentalistas"; (v) o valor da dignidade humana engloba a possibilidade de o ser humano responder pelas suas decisões existenciais, mas "essa concepção não pode ser levada ao extremo, sobretudo em um país como o Brasil, dotado de quantidade imensa de seitas e religiões"; (vi) a liberdade religiosa não pode impedir o Estado de "agir em defesa da vida humana ao ter ciência de que pessoas estão colocando em risco as próprias vidas - por fundamento religioso - e podem vir a atingir a esfera jurídica de terceiros", já que os médicos poderiam estar sujeitos a sanções administrativas, civis e criminais; (vii) a liberdade religiosa deve ser exercida de modo razoável e proporcional, e "a opção do Testemunha de Jeová viola (...) o princípio da razoabilidade (...)", na medida em que sacrifica o seu direito à vida; (viii) "a paciente, ao se dirigir ao hospital, optou pela salvação de sua vida, cabendo, portanto, o método e o tratamento final ao médico". Disponível em < http://www.pge.rj.gov.br/Boletins/Boletim200_mai2010.pdf $>$. Acessado em: 10 set. 2010.
} 
No entanto, estes não são os únicos fatores a serem avaliados e sopesados para se verificar a dimensão da autodeterminação corporal. É necessário verificar, também, a validade do consentimento nos atos de disposição sobre o próprio corpo, conforme será desenvolvido a seguir.

\section{3) Os limites da autonomia corporal à luz da dignidade da pessoa humana}

\subsection{1) O consentimento nos atos de disposição sobre o próprio corpo}

Juntamente com a autonomia privada, outros instrumentos jurídicos a ela ligados perderam seu aspecto puramente individualista e patrimonialista prevalecentes durante os séculos XVIII e XIX, para se adequar aos novos objetivos do ordenamento constitucional. Entre eles está o consentimento, instituto que durante o liberalismo jurídico era aplicado exclusivamente às relações econômicas, minimizando a importância das situações existenciais. No entanto, com a alteração do núcleo central do sistema jurídico para a proteção da pessoa humana, o conceito de consentimento também teve que ser modificado, moldando-s às novas diretrizes constitucionais.

Desse modo, tendo em vista a supremacia do princípio da dignidade da pessoa humana na nova ordem constitucional, a autonomia da vontade vigente no paradigma individualista deixa de ser um valor em si mesmo. Em consequência, houve a reformulação do conceito de consentimento, que passou a ser tutelado apenas nos casos em que importar na concretização da dignidade humana, ainda que isso signifique o sacrifício da vontade do sujeito $^{33}$.

Deve haver, então, a compatibilização entre a vontade e a proteção da pessoa, de modo que o consentimento somente será válido e merecedor

\footnotetext{
${ }^{33}$ KONDER, Carlos Nelson. O consentimento no biodireito: os casos dos transexuais e dos wannabes. Revista Trimestral de Direito Civil, vol. 15, jul.- set. 2003, p. 59.
} 
de tutela quando a manifestação do querer individual não resultar em violação de um dos aspectos da dignidade humana.

As premissas acima expostas se encaixam perfeitamente ao consentimento nos atos de disposição do próprio corpo. Existem casos em que a liberdade e a vontade individual deverão ser afastadas por implicarem na violação à dignidade humana, enquanto que, por outro lado, deverá o consentimento ser protegido nas hipóteses em que importar na manifestação da personalidade.

É possível afirmar, portanto, que os atos de autonomia corporal, manifestados através do consentimento, serão merecedores de tutela na medida em que conduzirem ao livre desenvolvimento da personalidade do seu titular, de modo a garantir a realização da dignidade da pessoa humana.

Contudo, é muito tênue a linha que divide os atos de disposição sobre o próprio corpo como efetiva promoção da personalidade daqueles considerados como manifestação de uma patologia. Assim, verifica-se que o consentimento não é por si só suficiente para determinar a legitimidade de tais atos, devendo ser analisado à luz do princípio da dignidade da pessoa humana. Nesse sentido, entende Pietro Perlingieri, segundo o qual:

"[...] o simples consentimento de quem tem o direito não é suficiente para tornar lícito o que para ordenamento é ilícito, nem pode - sem um retorno ao dogma da vontade como valor - representar um ato de autonomia de per si merecedor de tutela". ${ }^{34}$

Assim, no que tange às relações existenciais, categoria na qual se insere a autodeterminação corporal, o valor principal a ser perseguido é a dignidade da pessoa humana, consubstanciada nos princípios da igualdade, integridade, solidariedade e liberdade. Desse modo, a vontade individual não basta para legitimar os atos de disposição corporal, visto que a

\footnotetext{
${ }^{34}$ PERLINGIERI, Pietro. Perfis do direito civil. Op. Cit. p. 299.
} 
liberdade é apenas um dos meios pelo qual a dignidade da pessoa humana se concretiza ${ }^{35}$.

Portanto, é perfeitamente possível a proibição de um ato de disposição sobre o corpo, mesmo que contra a vontade do seu titular, se este configurar uma ofensa a um dos aspectos da dignidade humana. É o caso, por exemplo, dos portadores de apotemnofilia (body integrity identity disorder-BIID), também chamados de amputees by choice ou wannabes, pessoas que, apesar de fisicamente saudáveis, sofrem de um distúrbio psicológico que as fazem desejar a amputação de algum de seus membros.

Trata-se de um desvio de identidade, visto que os wannabes têm o sentimento de que "nasceram no corpo errado" e que somente serão eles mesmos se amputarem algum membro. Alguns relatam a existência desse desejo desde a infância, situação que se torna insuportável com o passar dos anos, transformando-se em uma obsessão pela amputação ${ }^{36}$.

São atos severos e radicais de disposição sobre o corpo que importam na diminuição permanente da integridade física, não sendo, portanto, merecedores de chancela jurídica. Não é razoável, nesses casos, que prevaleça a vontade do indivíduo, devendo o ordenamento jurídico zelar pela sua saúde e proteger a sua dignidade. Como ainda não há regulamentação médica autorizando a cirurgia, entende-se que a manutenção da integridade física, como direito da personalidade, deve preponderar em detrimento da liberdade individual, aplicando-se o artigo 13 do Código Civil.

Por mais que esses atos sejam manifestações da identidade, conforme afirmam os portadores de tal distúrbio, a autorização da cirurgia

\footnotetext{
${ }^{35}$ VENCELAU, Rose Melo. Autonomia privada e dignidade humana. Op. Cit. p. 93.

${ }^{36}$ Informações obtidas em: What drives people to want to be amputees? In: ABC News. Disponível em: 〈http://abcnews.go.com/Primetime/Health/story?id=1806125\&page=3 $>$. Acessado em 18 set. 2010; Carl Elliot. A new way to be mad. In: The Atlantic Monthly, dez. 2000. Disponível em $<$ http://www.theatlantic.com/past/docs/issues/2000/12/elliott.htm>. Acessado em 18 set. 2010.

Nos referidos artigos, são relatados diversos casos de pessoas com desejo compulsivo pela amputação, como Lilly e Karl, que para forçar a realização da cirurgia, mergulharam as pernas durante horas em gelo seco até que elas perdessem sua função, de modo que não houvesse outra saída para os médicos senão a amputação.
} 
de amputação apenas com base na vontade dessas pessoas seria uma atitude precipitada. Ainda que no futuro a comunidade médica entenda ser este tratamento radical o mais adequado para esses casos, no atual momento, ele parece mais ferir a dignidade destas pessoas do que propriamente realizá1a. ${ }^{37}$

No entanto, em nome da autonomia existencial, o Estado não atribui qualquer consequência jurídica a esses atos radicais de disposição sobre o próprio corpo, senão quando forem praticados com dolo de fraudar terceiros, como, por exemplo, uma seguradora ou uma instituição previdenciária. Desse modo, apesar de tais atos não serem merecedores de tutela jurídica, o ordenamento não penaliza os indivíduos que praticam a autolesão.

Entende-se, contudo, pela imposição de sanção ao profissional que eventualmente anuir em amputar um membro de um paciente, mesmo que com o seu consentimento, devendo tal conduta ser imputada como lesão corporal gravíssima ${ }^{38}$. Nesse caso, a simples vontade não é capaz de legitimar o ato de disposição sobre o corpo, de modo que não pode um médico proceder à intervenção cirúrgica apenas com base no querer do paciente.

Por outro lado, há o caso dos transexuais, que realizam a cirurgia de transgenitalização em razão da inadequação entre o sexo biológico e o sexo psicossocial. Apesar de haver diminuição permanente da integridade física, tal cirurgia é considerada lícita, sendo justificada e autorizada em virtude de sua finalidade terapêutica, tendo em vista o desvio psicológico de identidade sexual que acomete os transexuais.

Nesse sentido, disciplina Raul Choeri:

\footnotetext{
${ }^{37}$ KONDER, Carlos Nelson. Op. cit., p. 66.

${ }^{38}$ Conduta tipificada no artigo $129, \S 2^{\circ}$, III do Código Penal brasileiro:

Art. 129. Ofender a integridade corporal ou a saúde de outrem:

$\S 2^{\circ}$ Se resulta:

III - perda ou inutilização do membro, sentido ou função

Pena - reclusão, de dois a oito anos.
} 
“[...] diante de uma situação psicológica irreversível e a inadaptação social, a opção recomendada é a correção física, através da cirurgia, que passa a ter caráter terapêutico, sob o aval da medicina e a pretensão de ser amplamente aceita pela sociedade e recepcionada pelo ordenamento jurídico". ${ }^{39}$

Porém, tal entendimento somente foi pacificado com a edição da Resolução $n^{\circ}$ 1.652/2002 do Conselho Federal de Medicina, que passou a permitir a intervenção cirúrgica para alteração do sexo, ressaltando a prescindibilidade de autorização judicial. $^{40}$

Nesta esteira, a doutrina civilista também é unânime ao defender a possibilidade de realização da referida cirurgia, tendo sido, inclusive, aprovado o Enunciado nº 276 na IV Jornada de Direito Civil do Conselho da Justiça Federal, que dispõe da seguinte forma:

"O art. 13 do Código Civil, ao permitir a disposição do próprio corpo por exigência médica, autoriza as cirurgias de transgenitalização, em conformidade com os procedimentos estabelecidos pelo Conselho Federal de Medicina, e a consequente alteração do prenome e do sexo no Registro Civil".

No que tange à bodymodification, como o assunto será tema do próximo capítulo, cumpre salientar apenas que constitui atos legítimos de disposição sobre o próprio corpo, visto que são manifestações da identidade pessoal. Desse modo, tal prática implica na exaltação natural da

\footnotetext{
39 CHOERI, Raul. Transexualismo e identidade pessoal: cirurgia de transgenitalização. In BARBOZA, Heloisa Helena; BARRETTO, Vicente de Paulo (org.). Temas de biodireito e bioética. Rio de Janeiro: Renovar, 2001, p. 234

${ }^{40}$ As Terceira e Quarta Turmas do Superior Tribunal de Justiça já autorizaram, inclusive, a alteração do prenome e do sexo de um transexual no Registro Público, conforme transcrição de julgado divulgado no Informativo de Jurisprudência $\mathrm{n}^{\circ}$. 411 da Corte: "O recorrente autor, na inicial, pretende alterar o assento do seu registro de nascimento civil, para mudar seu prenome, bem como modificar o designativo de seu sexo, atualmente constante como masculino, para feminino, aduzindo como causa de pedir o fato de ser transexual, tendo realizado cirurgia de transgenitalização. Acrescenta que a aparência de mulher, por contrastar com o nome e o registro de homem, causa-lhe diversos transtornos e dissabores sociais, além de abalos emocionais e existenciais. Assim, a Turma entendeu que, tendo o recorrente se submetido à cirurgia de redesignação sexual nos termos do acórdão recorrido, existindo, portanto, motivo apto a ensejar a alteração do sexo indicado no registro civil, a fim de que os assentos sejam capazes de cumprir sua verdadeira função, qual seja, a de dar publicidade aos fatos relevantes da vida social do indivíduo, deve ser alterado seu assento de nascimento para que nele conste o sexo feminino, pelo qual é socialmente reconhecido. Determinou, ainda, que das certidões do registro público competente não conste que a referida alteração é oriunda de decisão judicial, tampouco que ocorreu por motivo de redesignação sexual de transexual"(REsp 1.008.398-SP, 3ª Turma, Rel. Min. Nancy Andrighi, julgamento em 15 out.2009).
} 
personalidade, não devendo, portanto, ser reprimida, sob pena de violação da dignidade da pessoa humana.

Assim, considerando que o fundamento central para se verificar a legitimidade dos atos de disposição sobre o próprio corpo é o princípio da dignidade da pessoa humana, conclui-se que o simples consentimento não é capaz de legitimar tais atos em todo e qualquer caso. A vontade individual deverá, portanto, ser relativizada quando importar na violação de um dos aspectos da dignidade.

\subsection{2) Liberdade $X$ Integridade: conflito entre aspectos da dignidade da pessoa humana.}

Os atos de disposição sobre o próprio corpo podem ensejar, em muitos casos, conflitos entre os diversos aspectos da dignidade da pessoa humana. A autonomia privada corporal, decorrente do princípio da liberdade, pode colidir com a integridade, igualdade e solidariedade, caso em que a solução será alcançada por meio da ponderação ${ }^{41}$.

Inicialmente, forçoso salientar que não se trata de colisão entre duas ou mais esferas jurídicas distintas, mas sim de uma contraposição de valores inseridos no bojo de uma única esfera jurídica, de um único titular. Desse modo, tais conflitos decorrem da presença de interesses confrontantes nos casos em que há um único sujeito atuando sobre si mesmo.

Ademais, são hipóteses em que, tendo em vista a ausência de hierarquia entre os princípios em questão, o conflito será solucionado através da técnica da ponderação, de modo que, em um caso concreto individualmente considerado, deve-se examinar qual desses valores vai

\footnotetext{
${ }^{41}$ Nesse sentido, afirma Rose Melo Vencelau: "[...] na hipótese de a autonomia colidir com um dos princípios que constituem o arcabouço jurídico da dignidade humana, permitindo soluções diversas, o uso do método da ponderação vai ser de suma importância para analise do merecimento de tutela do ato de autonomia privada" (VENCELAU, Rose Melo. Autonomia privada e dignidade humana. Op. Cit., p. 195).
} 
prevalecer em detrimento do outro. Será avaliado, então, à luz de uma situação concreta, qual dos subprincípios é o mais adequado para ser aplicado.

O método da ponderação terá como critério a dignidade da pessoa humana, de modo que a solução do conflito deverá ser direcionada no sentido da sua concretização. Assim, a relativização desses princípios somente pode ser feita a fim de que a dignidade humana seja alcançada, já que se trata do valor máximo do ordenamento jurídico brasileiro.

Assim dispõe o Enunciado nº 274 da IV Jornada de Direito Civil do Conselho da Justiça Federal:

\footnotetext{
"Os direitos da personalidade, regulados de maneira não-exaustiva pelo Código Civil, são expressões da cláusula geral de tutela da pessoa humana, contida no art. $1^{\circ}$, inc. III, da Constituição (princípio da dignidade da pessoa humana). Em caso de colisão entre eles, como nenhum pode sobrelevar os demais, deve-se aplicar a técnica da ponderação".
}

No âmbito da autodeterminação corporal, os conflitos normalmente ocorrem entre a liberdade e a integridade psicofísica, uma vez que, conforme afirma Carlos Nelson Konder:

“[...] não são claros os limites entre a livre disposição do corpo como projeção do desenvolvimento da personalidade e identidade e a sua mutilação como ato patológico; entre o ato inconsequente de diminuição permanente da integridade física e o reconhecimento de uma finalidade terapêutica em tal intervenção". ${ }^{42}$

Nessas hipóteses, entende-se que, a priori, a liberdade deve prevalecer, tendo em vista a preocupação central do ordenamento jurídico com a tutela da pessoa e com o desenvolvimento dos direitos a ela inerentes. Nesse sentido, a autonomia corporal representa um espaço fundamental para a manifestação da personalidade e da identidade, devendo ser garantida plena liberdade para os indivíduos determinarem os aspectos

\footnotetext{
${ }^{42}$ KONDER, Carlos Nelson. Op. cit., p. 65.
} 
relativos à sua vida privada e ao seu corpo, de modo a haver a concretização da sua dignidade ${ }^{43}$.

Por outro lado, como anteriormente explicitado, existem casos em que, nesse juízo de ponderação, a liberdade deverá ser restringida, prevalecendo a proteção da integridade psicofísica, visto que garantir total autonomia corporal caracterizaria uma violação à dignidade da pessoa humana.

Observa-se, portanto, que não se pode conferir caráter absoluto à autonomia corporal, devendo preponderar, em cada caso concreto, a liberdade ou a integridade dependendo de qual desses valores promover, do modo mais amplo, o desenvolvimento da personalidade e a realização da dignidade.

Então, a título de conclusão, pode-se considerar que o artigo 13 do Código Civil não impõe barreiras intransponíveis ao direito ao próprio corpo. A interpretação de tal dispositivo exige que os interesses conflitantes sejam ponderados de acordo com os imperativos constitucionais, em vistas à concretização da dignidade da pessoa humana, sendo este o único limite insuperável dentro da ordem constitucional.

\footnotetext{
${ }^{43}$ Nesse sentido, entende Maria Celina Bodin de Moraes, segundo a qual, a liberdade individual "é tutelada expressamente por numerosas normas do sistema, a ressaltar a importância fundamental da autonomia privada, especialmente nas relações não-patrimoniais e nas decisões que dizem respeito à vida privada. Por outro lado, quanto à integridade psicofísica, o Estado não oferece tutela em face da própria pessoa, não atribuindo, normalmente, qualquer consequência jurídica a atos de autolesão, a não ser quando se pretende enganar terceiros" (BODIN DE MORAES, Maria Celina. Uma aplicação do princípio da liberdade. In: BODIN DE MORAES, Maria Celina. $\mathrm{Na}$ medida da pessoa humana: estudos de direito civil-constitucional. Rio de Janeiro: Renovar, 2009. p. 18). Thamis Dalsenter compartilha a mesma posição, ao dispor que: "a tônica de uma norma que se destine somente à tutelar a pessoa contra ela mesma deve ser sempre, em primeiro lugar, a liberdade" (DALSENTER, Thamis. Op. cit., p. 140).
} 


\section{Capítulo 4: 0 Caso da Bodymodification}

\section{1) A bodymodification como ato de disposição sobre o próprio corpo}

A bodymodification é uma prática de modificação deliberada e permanente do corpo humano, executada através do uso de produtos químicos e até de intervenções cirúrgicas, por motivos de ordem estética, cultural ou espiritual. A modificação corporal é um gênero no qual está inserido uma série de espécies como as tatuagens, piercings, branding, cutting, implantes subcutâneos, escarificação e suspensão. Pelos adeptos dessa prática, desenhos são tatuados por todo o corpo, piercings são colocados nos mais diferentes locais, orelhas e narinas são alargadas, as línguas são bifurcadas e peças de silicone são implantadas sob a pele.

Não se trata, contudo, de um fenômeno recente. Pode-se notar a prática milenar de alterações corporais desenvolvidas em civilizações tribais desde os tempos mais antigos. São práticas que manifestam a cultura e a tradição ${ }^{44}$ desses povos, como, por exemplo, o O-kee-pa, uma forma de auto tortura realizada através da suspensão em cerimônias religiosas nas tribos indígenas americanas, bem como os índios brasileiros Caiapó, que utilizam um botoque de madeira no lábio inferior, a fim de aprimorar a oratória e o canto dos chefes tribais. Além disso, a escarificação ${ }^{45}$, técnica de produção de desenhos na pele através de cicatrizes realizadas por instrumentos cortantes, foi muito utilizada em diversas culturas, como, por exemplo, pelos aborígenes australianos e da Nova Guiné em ritos de

\footnotetext{
44 "Nas sociedades pré- letradas existiam basicamente dois tipos de rituais onde as marcas corporais eram feitas: os dedicados a preparar o indivíduo para uma determinada atividade ou situação, que tinham ligação com o tempo cronológico e aconteciam por causa da faixa etária em que o sujeito se encontrava, e os voltados a registrar seus feitos heróicos, que não possuíam essa ligação e, normalmente, eram executados depois de guerras e caçadas". PIRES, Beatriz Ferreira. O corpo como suporte da arte. Revista Latino-americana de Psicopatologia Fundamental, n.1, mar.2003, p.81. Disponível em $\langle$ http://www.ufrnet.br/ tl/otherauthorsworks/dat0142/pires_corpo_suporte_arte.pdf $>$. Acessado em 16 set. 2010.

${ }^{45}$ Ver item 1 do Anexo I.
} 
passagem e pelas mulheres das tribos africanas como forma de embelezamento $^{46}$.

Nas sociedades contemporâneas, a banalização do corpo e a homogeneização dos padrões estéticos germinaram nos indivíduos o desejo de criar uma identidade única, que os diferencie dos demais. Por isso, eles se "apropriam" do seu corpo e, aproveitando-se dos avanços científicos e tecnológicos, formam novas dimensões estéticas, nas quais são expressos os seus desejos e convicções pessoais.

No aspecto psicanalítico, a bodymodification é vista como uma maneira de resgatar o inconsciente através da sua representação no corpo. As memórias, impressões e os sentimentos, anteriormente retidos somente na dimensão psíquica, passam a se manifestar ao mundo exterior, através das modificações da esfera física ${ }^{47}$.

Com isso, entende-se que as diversas formas de alterações corporais representam um prolongamento da mente, uma vez que são manifestações do inconsciente dos indivíduos. É uma forma de:

"[...] dar oportunidade ao psíquico de expressar-se concretamente sobre o suporte ao qual está vinculado, de trazer à tona e vivenciar o inconsciente, de materializar o imaterial, como uma forma do indivíduo conectar-se ao universo". ${ }^{48}$

Pelos adeptos dessa prática, o corpo é visto como um instrumento, como uma tela em branco, apto a ser modificado e manipulado para satisfazer e expressar seus anseios pessoais. A bodymodification, portanto, rompe a fronteira da pele, permitindo a realização de interferências que visam modificar a silhueta, através da implantação de novos elementos ao corpo humano, o que, muitas vezes, acaba alterando por completo a sua anterior aparência.

\footnotetext{
46 Informações obtidas em 〈http://wiki.bmezine.com> e < http://fzerostudio.com.br/wp/> Acessado em 17 set. 2010.

${ }^{47}$ PIRES, Beatriz Ferreira. Op. Cit. p. 79.

${ }^{48}$ Ibid. p. 80.
} 
Assim, os indivíduos alteram a constituição tradicional dos seus corpos, criando uma identidade própria e fugindo do enquadramento social natural. Não se trata de uma patologia ligada à esfera psíquica dos adeptos das modificações corporais, mas da manifestação da sua personalidade, direcionada no sentido de resistência ao senso comum, aos padrões socialmente aceitos como "normais".

Há, com isso, o surgimento de novas formas corporais que quase sempre causam um desconforto, um estranhamento pela sociedade. São práticas contrárias às convenções sociais e, portanto, consideradas como bizarras pelas pessoas em geral. No entanto, as alterações corporais vêm sendo constantemente utilizadas, principalmente de forma mais branda, através das tatuagens e piercings.

Portanto, tais atos devem ser analisados sob a perspectiva dos princípios democráticos constitucionais que orientam o ordenamento jurídico no sentido do respeito ao pluralismo e à diferença, visto que caracterizam uma forma de expressão da personalidade.

\section{2) A bodymodification como forma de manifestação da personalidade.}

Com as alterações corporais, os desejos íntimos dos seus adeptos, anteriormente reservados à sua esfera psíquica, passam a ser refletidos no corpo, relacionando-se com o meio externo. O corpo vira, portanto, palco para a realização das vontades subjetivas do seu titular, sendo modificado e moldado de acordo com os seus anseios pessoais.

Há, com isso, a exaltação da individualidade pessoal, através da criação de novas configurações corporais. Os indivíduos se tornam diferentes do padrão estético tradicional, criando uma identidade única, o assegurando-lhes efetiva promoção da sua personalidade. 
O direito à identidade pessoal foi consagrado pela jurisprudência italiana como um direito da personalidade autônomo, tendo sido conceituado como "um bem em si mesmo, independentemente da condição pessoal e social, das virtudes e dos defeitos do sujeito, de modo que a cada um é reconhecido o direito a que sua individualidade seja preservada". ${ }^{49}$

Desse modo, pode-se afirmar que a identidade pessoal traduz o "direito de ser si mesmo", compreendido como o conjunto de características físicas, convicções religiosas, ideológicas e morais que servem para individualizar e diferenciar as pessoas perante o meio social. Os indivíduos são livres para criar sua identidade, a forma pela qual serão representados perante a sociedade ${ }^{50}$.

A prática da bodymodification pode ser considerada como uma expressão dessa identidade pessoal, visto que é a manifestação da individualidade e da subjetividade através do corpo. Configura-se, portanto, como instrumento de ampla promoção e livre desenvolvimento da personalidade, sendo tais atos de disposição sobre corpo dignos de tutela jurídica, sob pena de negação da dignidade da pessoa humana concretizada através da liberdade existencial.

Ademais, em uma sociedade plural, cuja Constituição apregoa o respeito pela alteridade, a tolerância e a não-discriminação, não seria razoável a intervenção do poder público na esfera da autonomia corporal, no sentido de coibir a prática de tais atos de disposição sobre o próprio corpo. Haveria, com isso, violação à dignidade da pessoa humana, valor supremo consagrado pelo texto constitucional, conforme entende Thamis Dalsenter:

“[...] Em muitos casos, o conteúdo dos variados planos de vida individuais podem parecer estranhos e sem sentido, entretanto, sob pena de efetuar-se um discurso

\footnotetext{
${ }^{49}$ Corte Constituzionale italiana, Sentenza $n^{\circ} .13$, de 1994. Apud. BODIN DE MORAES, Maria Celina. Ampliando os direitos da personalidade. Op. Cit., p. 382.

${ }^{50}$ BODIN DE MORAES, Maria Celina. Ampliando os direitos da personalidade. Op. Cit., p. 381.
} 
autoritário com a defesa de opiniões particulares, deve-se alocá-los nos espaços destinados ao pluralismo democrático consagrado na Carta Magna". ${ }^{51}$

As alterações corporais revelam, portanto, a exaltação da personalidade, garantindo a coexistência harmônica entre as esferas física e psíquica dos seus adeptos, ainda que isso importe na diminuição da primeira para satisfação dos desejos da segunda. Desse modo, por mais que sejam considerados pelo senso-comum como irracionais, essa prática não deve ser reprimida pelo ordenamento jurídico, tornando-se necessário assegurar plena autonomia aos indivíduos para realizarem modificações em seu corpo.

A título de ilustração, pode ser mencionado o caso de Erik Sprague, mais conhecido como The Lizardman ${ }^{52}$, que para ter a aparência semelhante à de um lagarto, realizou uma série de modificações corporais. Após diversas sessões de tatuagens que cobriram o seu corpo de escamas verdes, implantes de esferas de silicone sob a pele do supercílio, bifurcação da língua e modelagem de seus dentes, adquiriu a aparência completa de um réptil. Para isso, abandonou seu doutorado em filosofia e, atualmente, realiza performances em shows ao redor do mundo ${ }^{53}$.

Dennis Avner, chamado de Stalking $\mathrm{Cat}^{54}$, também realizou várias alterações corporais com o objetivo de que sua imagem se aparentasse à de um tigre. Para tal, tatuou complemente seu corpo à semelhança da pelagem de tal animal, aplicou silicone na parte superior dos lábios e implantou fios para simular os bigodes felinos. Ao final de todas as modificações, tornouse efetivamente o homem-tigre ${ }^{55}$.

\footnotetext{
${ }^{51}$ Thamis Dalsenter. Op. Cit., p. 145.

${ }^{52}$ Ver item 2 do Anexo I.

${ }^{53}$ Informações obtidas em <http://wiki.bmezine.com/index.php/The Lizardman>. Acessado em 17 set. 2010.

${ }^{54}$ Ver item 3 do Anexo I.

55 Informações disponíveis em <http://pt.wikipedia.org/wiki/Stalking_Cat〉. Acessado em 17 set. 2010 .
} 
Rick Genest, por sua vez, não tinha o desejo de se tornar um animal, mas sim um zumbi. Conhecido como Zombie Rick ${ }^{56}$, gastou mais de R\$ 13 mil para cobrir seu corpo de tatuagens que simulam um esqueleto e afirma que quer reproduzir em seu próprio corpo a imagem de um cadáver em decomposição ${ }^{57}$.

Por outro lado, existem formas de modificações corporais que não representam manifestações artísticas, como, por exemplo, as suspensões ${ }^{58}$. Nestes atos, um conjunto de roldanas é ligado a ganchos implantados sob a pele dos adeptos dessa prática, suspendendo-os a uma altura entre 30 e 60 centímetros do chão. A suspensão não só é utilizada como forma de entretenimento e arte performática, mas também para meditação, com o objetivo de elevar os níveis de consciência e realização espiritual ${ }^{59}$.

Então, em relação à bodymodification, no juízo de ponderação entre os interesses conflitantes, prevalece a liberdade em detrimento da integridade, sendo permitido o consentimento na realização desses atos, de maneira a garantir a concretização do princípio da dignidade da pessoa humana.

São práticas que por si só diminuem a integridade física daqueles que as realizam, podendo, inclusive causar conseqüências ainda mais graves, visto que é alto o risco de infecções e inflamações. No entanto, sendo realizadas por pessoas dotadas de capacidade e discernimento, que gozem de aptidão jurídica para assumir a responsabilidade, suportar as suas conseqüências e, principalmente aceitar a sua provável irreversibilidade, não cabe ao Estado reprimi-las.

Dessa maneira, deve ser assegurado aos indivíduos amplo campo de liberdade para a alteração do próprio corpo, garantindo a autonomia

\footnotetext{
${ }^{56}$ Ver item 4 do Anexo I.

${ }^{57}$ Dados encontrados em < http://www.redhairtattoo.com/2009/09/pessoas-mais-modificadas-domundo-rick.html>. Acessado em 17 set. 2010.

${ }^{58}$ Ver item 5 do Anexo I.

${ }^{59}$ Informações obtidas em <http://pt.wikipedia.org/wiki/Suspens\%C3\%A3o_corporal >. Acessado em 17 set. 2010.
} 
corporal para a prática da bodymodification. Os adeptos das modificações corporais sabem dos riscos que estão assumindo ao dispor do seu corpo, têm conhecimento das complicações que podem ser causadas pelas tatuagens, piercings, suspensões, escarificações e diversas outras formas de alterações corporais. Então, se ainda assim aceitam as consequiências e resolvem fazer tais modificações, o Estado não pode impedir ou proibir.

Por fim, é possível afirmar que a repressão estatal contra a bodymodification seria uma atitude autoritária, incompatível com as diretrizes do nosso ordenamento constitucional democrático e pluralista, devendo ser respeitado o exercício da autonomia corporal como forma de exaltação e promoção da personalidade e de criação de uma identidade pessoal. 


\section{Conclusão}

A mudança paradigmática ocorrida no século $\mathrm{XX}$ orientou a elevação da pessoa humana à categoria de valor central do ordenamento jurídico, de modo que a preocupação pela sua promoção e tutela se irradiou por todos os ramos do direito. Assim, foi necessária a compatibilização dos setores jurídicos a essa nova perspectiva constitucional, através da criação ou da adequação de seus institutos na direção da concretização da dignidade da pessoa humana.

Nesse contexto, ao lado da antiga visão de autonomia privada patrimonial, surgiu a noção de autonomia existencial, instituto responsável por assegurar aos indivíduos o poder de autodeterminação em relação aos seus interesses extrapatrimoniais. De acordo com a doutrina civilconstitucional, a autonomia existencial é uma forma de tutela positiva da pessoa humana, na medida em que é capaz de determinar o livre desenvolvimento da personalidade e, em última instância, de realizar os princípios constitucionais, principalmente a dignidade da pessoa humana.

Em igual sentido, há que se considerar a noção de autonomia corporal, capacidade de autodeterminação e disposição do corpo humano de acordo com as convicções pessoais do seu titular. O corpo é entendido um instrumento de manifestação da personalidade, razão pela qual deve ser assegurada ampla liberdade aos seus titulares para dele dispor. Desse modo, a tutela da integridade psicofísica deve ser definida a partir das próprias escolhas dos indivíduos, a fim de que seja realizada a dignidade da pessoa humana.

Adotando posicionamento contrário, o legislador civilista impôs limitações à autonomia existencial em relação ao exercício dos direitos da personalidade, esvaziando a possibilidade de disposição pelo seu titular. Especificamente no que se refere à integridade física, o artigo 13 do Código Civil estabeleceu limites extremamente rígidos que não permitem o pleno 
exercício da autonomia corporal, impossibilitando quase completamente os atos de disposição sobre o próprio corpo.

Desse modo, verifica-se que, à luz da doutrina civil-constitucional, a tutela da personalidade proposta pelo Código Civil brasileiro não é suficiente para garantir ampla proteção à pessoa humana, tendo em vista que essa excessiva restrição dos interesses extrapatrimoniais colide com a necessidade de promoção e de desenvolvimento da personalidade.

É necessário, portanto, interpretar tal dispositivo legal à luz da Constituição, pautando a tutela da personalidade nos princípios constitucionais, principalmente na dignidade da pessoa humana, sem restringi-la aos casos previstos em lei.

Nesse sentido, torna-se imprescindível a ampliação da autonomia privada existencial, tendo em vista a sua inegável importância para a tutela positiva da pessoa humana e, consequentemente, para assegurar a sua dignidade. Desse modo, deve-se garantir aos indivíduos capacidade de realizar os seus desejos pessoais e concretizar as suas próprias escolhas, inclusive em relação ao seu corpo.

Entretanto, no que tange à autonomia corporal, faz-se necessário, ainda, verificar a legitimidade dos atos de disposição sobre o próprio corpo, tendo em vista o potencial conflito entre a liberdade e os demais princípios formatadores da dignidade da pessoa humana, tais como a integridade, solidariedade e igualdade.

Assim, não se pode conferir caráter absoluto à autonomia corporal, sendo necessário ponderar, em cada caso concreto, qual desses valores é capaz de promover, do modo mais amplo, o desenvolvimento da personalidade.

É possível afirmar, portanto, que a legitimidade dos atos de disposição sobre o próprio corpo deve ter como limite a própria dignidade. Assim, em caso de conflitos entre a liberdade e outros princípios constitucionais, a solução deve ser alcançada pela técnica da ponderação, 
utilizando-se como critério a dignidade da pessoa humana, o único limite que não pode deixar de ser observado.

Então, o simples consentimento, como forma de manifestação da autonomia existencial, não é por si só suficiente para permitir a prática de todo e qualquer ato de disposição do próprio corpo, sendo necessário avaliar a sua legitimidade à luz da dignidade da pessoa humana.

Nesse sentido, os atos de disposição sobre o próprio corpo que importam em violação da dignidade humana não merecem chancela do ordenamento jurídico, devendo a sua prática ser reprimida, mesmo que contra a vontade do titular do direito. São casos em que, no juízo de ponderação, a integridade física deve prevalecer sobre a liberdade, visto que o exercício ilimitado da autonomia corporal implicará em lesão à dignidade humana.

Por outro lado, existem atos de disposição sobre o próprio corpo que determinam o desenvolvimento e a promoção da personalidade, como é o caso da bodymodification. Nessas hipóteses, o corpo é visto como um espaço de liberdade, um instrumento de criação e exaltação da identidade pessoal. Entende-se, portanto, que a restrição da autonomia corporal faltamente violaria a dignidade da pessoa humana, sendo necessário afastar a indisponibilidade do corpo e assegurar total liberdade aos indivíduos para realizarem as alterações corporais.

Diante do exposto, conclui-se que a interpretação do artigo 13 do Código Civil deve ser direcionada no sentido dignidade da pessoa humana, de maneira que os limites por ele impostos serão ultrapassados quando os atos de disposição sobre o próprio corpo possuírem caráter promocional, no sentido de garantir o desenvolvimento da personalidade. 


\section{Referências Bibliográficas}

AZEVEDO, Antonio Junqueira. Caracterização jurídica da dignidade da pessoa humana. Revista Trimestral de Direito Civil - RTDC, n. 9, jan./mar. 2002.

BARBOZA, Heloisa Helena. Perspectivas do direito civil brasileiro para o próximo século. Revista da Faculdade de Direito da UERJ, nº 6.

BARROSO, Luis Roberto. Neoconstitucionalismo e constitucionalização do direito (o triunfo tardio do Direito Constitucional no Brasil). Revista Eletrônica sobre a Reforma do Estado-RERE, n. 09, 2007.

BITTAR, Carlos Alberto. Os direitos da personalidade. Rio de Janeiro: Forense, 2008.

BODIN DE MORAES, Maria Celina. A caminho de um direito civil constitucional. Direito, Estado e Sociedade: Revista do Departamento de Direito da PUC-Rio, n. 1, 2. ed.. Rio de Janeiro: PUC-Rio, jul./dez. 1991, p. $59-73$.

Ampliando os direitos da personalidade. In: José Ribas Vieira. (Org.). 20 anos da Constituição cidadã de 1988: efetivação ou impasse institucional?. Rio de Janeiro: Forense, 2008.

Tendências, in Revista dos Tribunais, vol. 779, 2000.

Danos à Pessoa Humana. Uma

leitura civil-constitucional do dano moral. Rio de Janeiro: Renovar, 2004. 
- Uma aplicação do princípio da liberdade. In: BODIN DE MORAES, Maria Celina. Na Medida da Pessoa Humana: Estudos de direito civil-constitucional. Rio de Janeiro: Renovar, 2009.

. O Princípio da dignidade humana.

In: BODIN DE MORAES, Maria Celina (Coord.). Princípios do direito civil contemporâneo. Rio de Janeiro: Renovar, 2006.

O princípio da solidariedade. In:

PEIXINHO, Manoel Messias; GUERRA, Isabella Franco; FILHO, Firly Nascimento (orgs.). Os princípios da constituição de 1988. Rio de Janeiro: Lumen Juris, 2001.

CHOERI, Raul. Transexualismo e Identidade Pessoal: Cirurgia de trangenitalização. In BARBOZA, Heloisa Helena; BARRETTO, Vicente de Paulo (org.). Temas de biodireito e bioética. Rio de Janeiro: Renovar, 2001.

DALSENTER, Thamis. Corpo e autonomia: a interpretação do artigo 13 do Código Civil brasileiro. Rio de Janeiro. 2009. 162 p. Tese (Mestrado em Direito) - Departamento de Direito da PUC-Rio.

DONEDA, Danilo. Os direitos da personalidade no Código Civil. In: TEPEDINO, Gustavo (Coord.). A parte geral do novo Código Civil: estudos na perspectiva civil-constitucional. Rio de Janeiro: Renovar, 2006

FACHIN, Luiz Edson; PIANOVSKI, Carlos Eduardo. A dignidade da pessoa humana no direito contemporâneo: uma crítica da raiz dogmática do neopositivismo constitucionalista. Revista Trimestral de Direito Civil $R T D C$, vol. 35, 2008. 
FINGER, Júlio César. Constituição e direito privado: algumas notas sobre a chamada constitucionalização do direito civil. In: SARLET, Ingo Wolfgang (Org.). A Constituição concretizada: construindo pontes com o público e o privado. Porto Alegre: Livraria do Advogado, 2000.

KONDER, Carlos Nelson. O consentimento no biodireito: Os casos dos transexuais e dos wannabes. Revista Trimestral de Direito Civil, vol. 15, jul.- set. 2003

NÁUFEL, José. Novo dicionário jurídico brasileiro. Rio de Janeiro: Forense, 2008.

PERLINGIERI, Pietro. O direito civil na legalidade constitucional. Rio de Janeiro: Renovar: 2008.

Perfis do direito civil. Rio de Janeiro: Renovar, 1999.

PIRES, Beatriz Ferreira. O corpo como suporte da arte. Revista Latinoamericana de Psicopatologia Fundamental, n.1, mar.2003. Disponível em <http://www.ufrnet.br/ tl/otherauthorsworks/dat0142/pires_corpo_suporte_

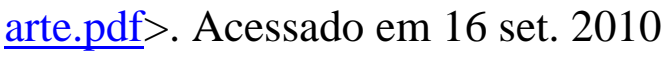

RODOTÁ, Stefano. Transformações do corpo. Revista Trimestral de Direito Civil - RTDC, n. 19, jul./set.2004.

RODRIGUES JÚNIOR, Álvaro. A recusa ao pagamento de indenização por invalidez total em contrato de seguro e o abuso de direito. Disponível em: $<$ http://www.buscalegis.ccj.ufsc.br/revistas/index.php/buscalegis/article /viewFile/9790/9356>. Acessado em 20 set. 2010

SARLET, Ingo Wolfgang. Dignidade da pessoa humana e direitos fundamentais. Porto Alegre: Livraria do Advogado, 2006. 
Superior Tribunal de Justiça. Recurso Especial $n^{\circ}$. 1.008.398-SP. Terceira Turma. Ministra Relatora Nancy Andrighi. Julgamento em 15.out.2009. Disponível em 〈www.stj.jus.br $>$. Acessado em 20 set.2010.

SZANIASKI, Elimar. Direitos da personalidade e sua tutela. São Paulo: Editora Revista dos Tribunais, $2^{\mathrm{a}}$ ed., 2005.

TEPEDINO, Gustavo. Premissas metodológicas para a constitucionalização do direito civil. In: TEPEDINO, Gustavo. Temas de Direito Civil, Rio de Janeiro: Renovar, 2004.

A tutela da personalidade no ordenamento civilconstitucional brasileiro. In: TEPEDINO, Gustavo. Temas de Direito Civil, Rio de Janeiro: Renovar, 2004.

- (et.al.) Código Civil interpretado conforme a

Constituição da República. Rio de Janeiro: Renovar, 2004.

. Os 15 anos da Constituição e o direito civil. Editorial da Revista Trimestral de Direito Civil - RTDC, n. 14, abr./jun. 2003, p. VVI.

VENCELAU, Rose Melo. Apontamentos sobre o papel da vontade nas situações jurídicas existenciais. Revista Trimestral de Direito Civil-RTDC, n.25, jan./mar.2006.

Autonomia privada e dignidade humana. Rio de Janeiro: Renovar, 2009. 


\section{Anexo I}

1) Escarificação ${ }^{60}$

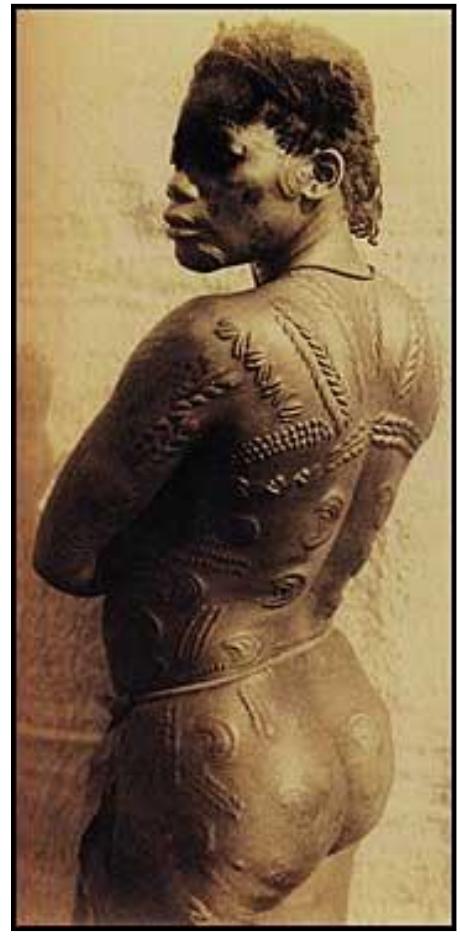

Foto 1.1

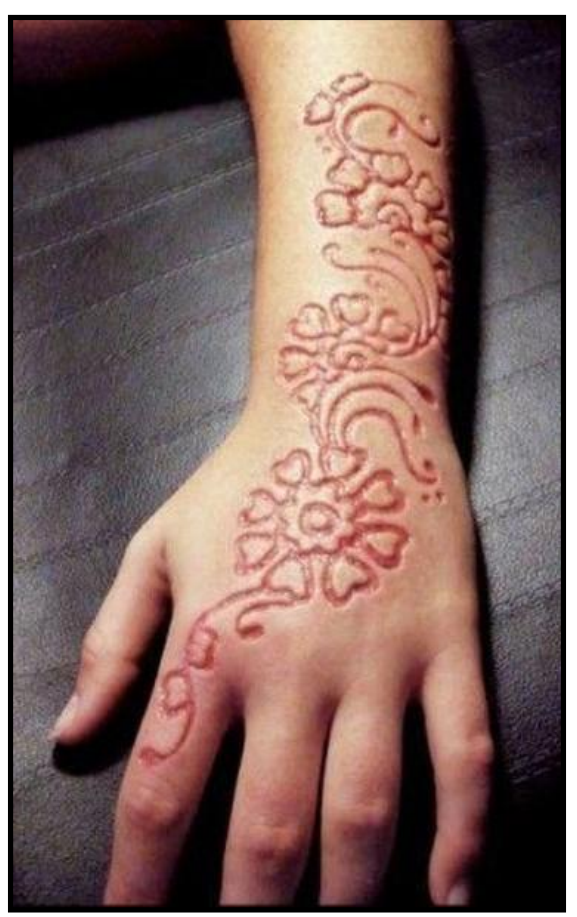

Foto 1.3

\footnotetext{
${ }^{60}$ Fonte: 〈http://www.bmezine.com>
}

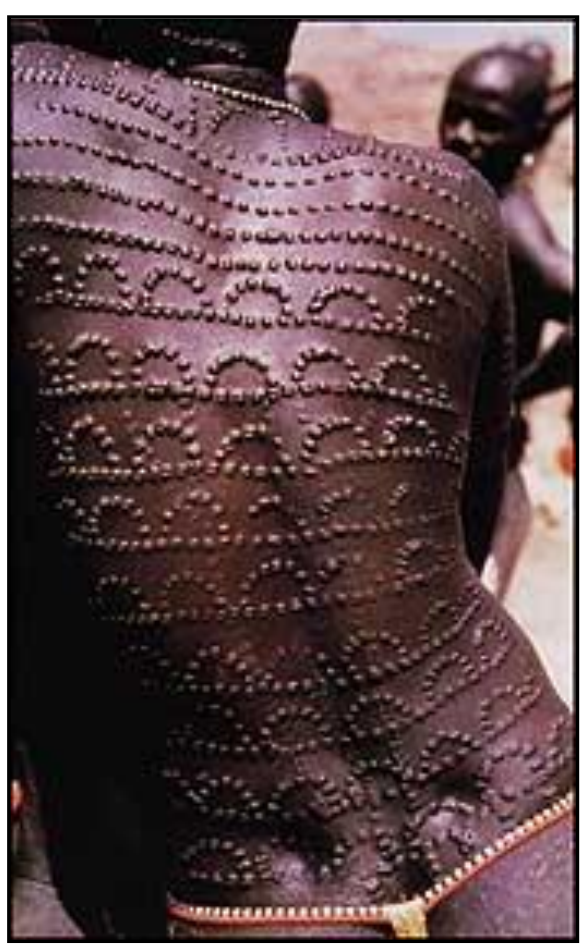

Foto 1.2 
2) O homem-lagarto (The Lizardman) ${ }^{61}$

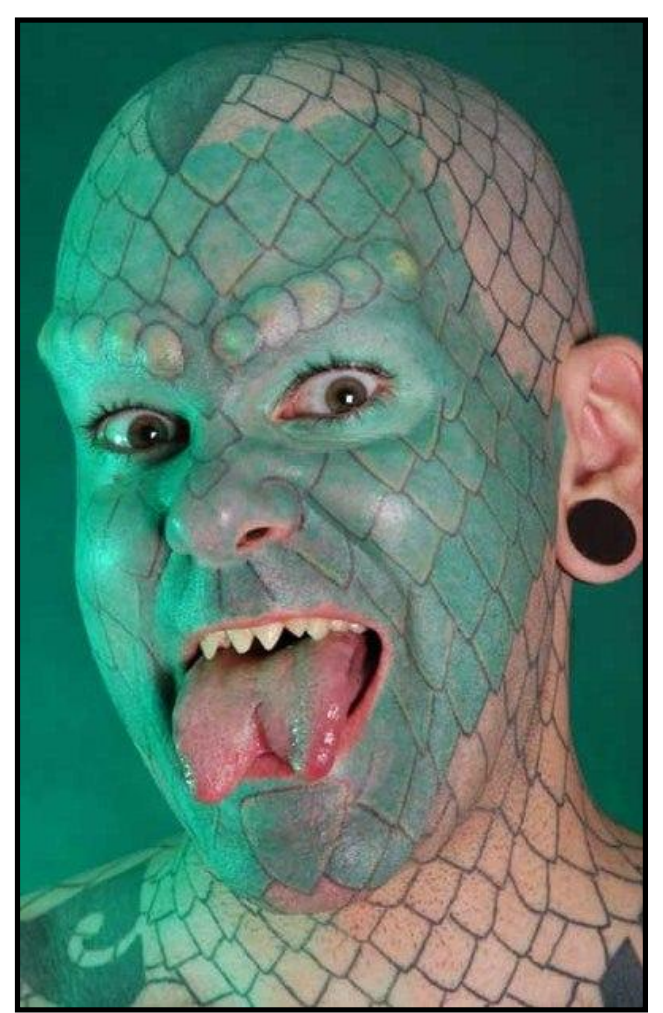

Foto 2.1

3) $\mathrm{O}$ homem-tigre (Stalking Cat) ${ }^{62}$

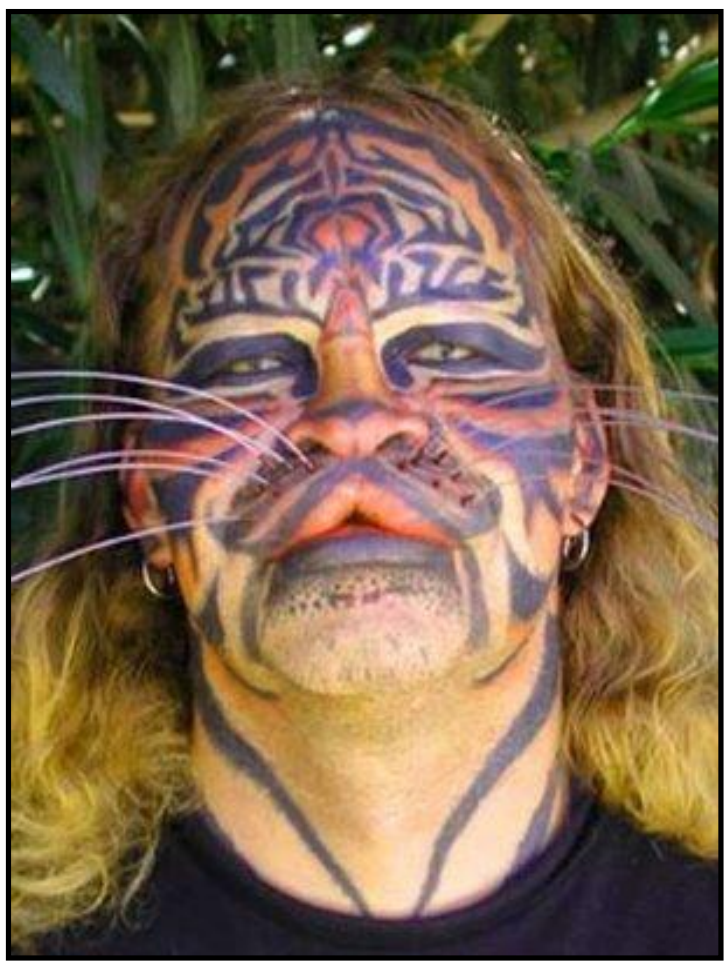

Foto 3.1

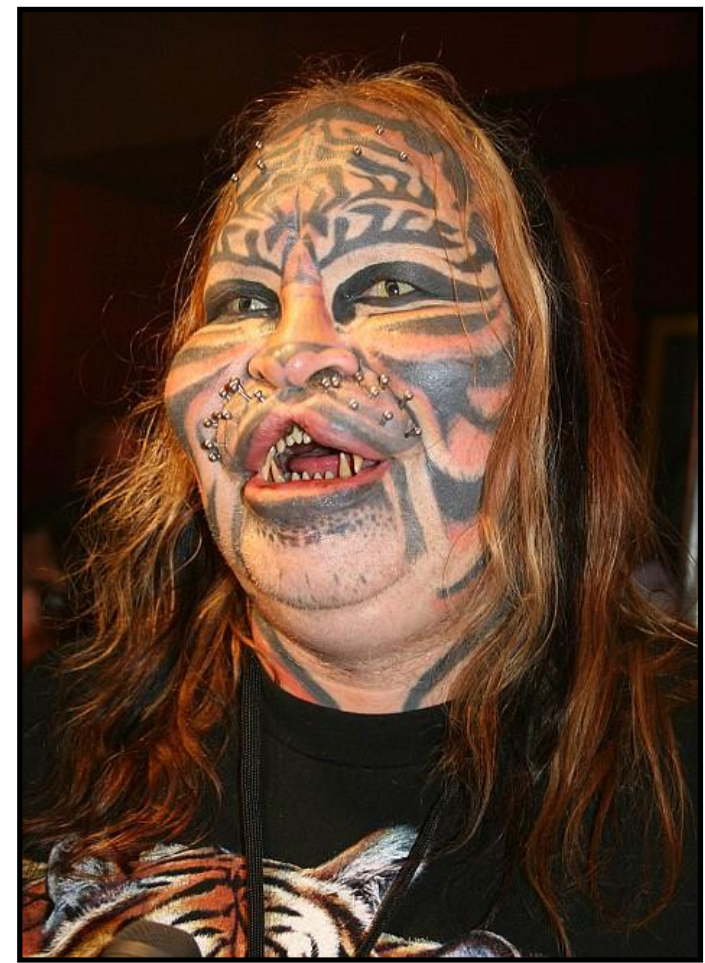

Foto 3.2

\footnotetext{
${ }^{61}$ Fonte: $\langle$ http://www.thelizardman.com $>$

${ }^{62}$ Fonte: $<$ http://www.stalkingcat.net $>$
} 
4) O homem-zumbi (Zombie Rick) $)^{63}$

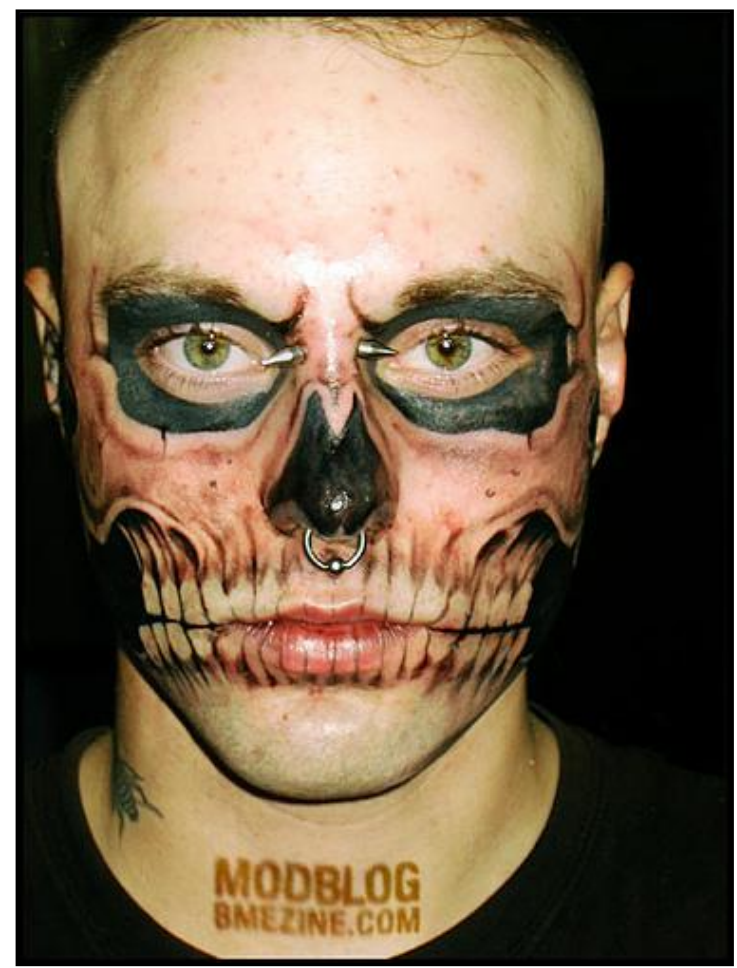

Foto 4.1

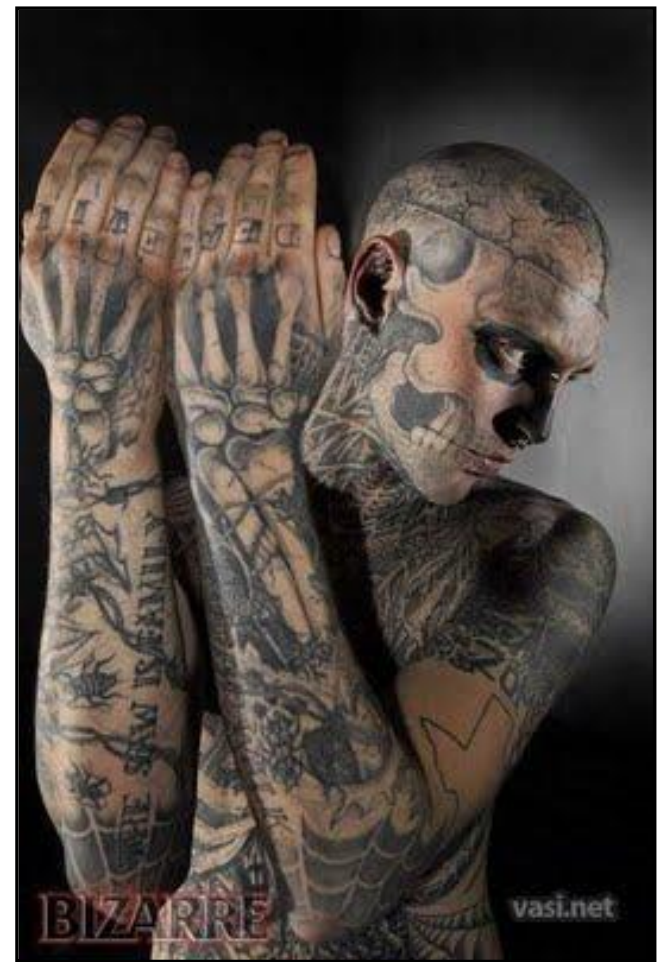

Foto 4.2

\section{5) Suspensão Corporal ${ }^{64}$}

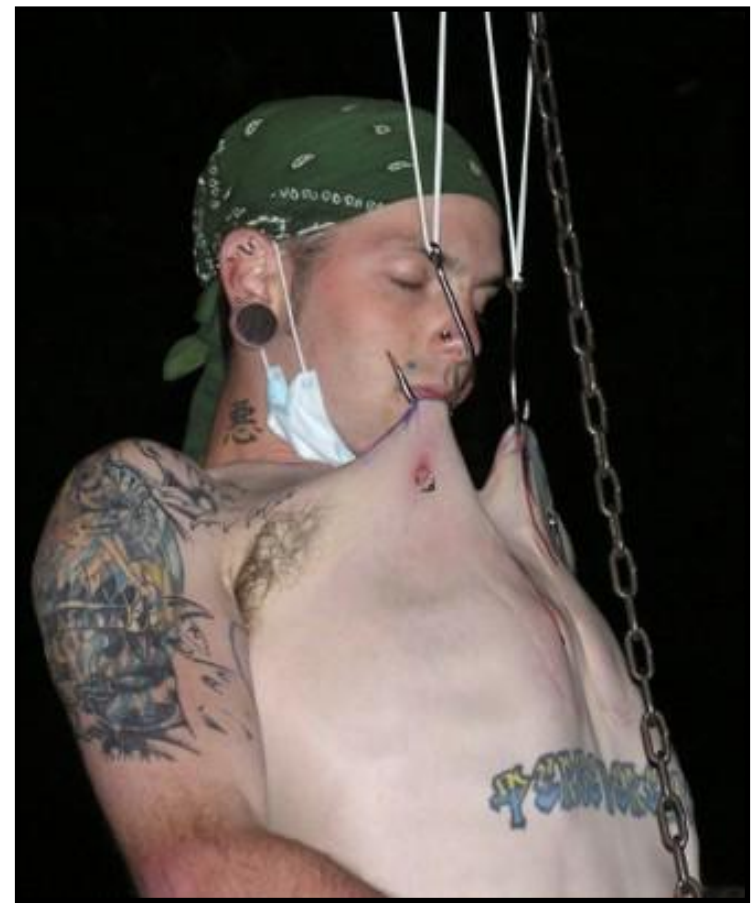

Foto 5.1

\footnotetext{
${ }^{63}$ Fonte: $\langle$ http://www.redhairtattoo.com/2009/09/pessoas-mais-modificadas-do-mundo-rick.html $>$

${ }^{64}$ Fonte: <http://pt.wikipedia.org/wiki/Suspens\%C3\%A3o corporal >
} 